\title{
Vaccines and Therapeutics Against Hantaviruses
}

\author{
Rongrong Liu't, Hongwei Ma't, Jiayi Shu'2,3, Qiang Zhang', Mingwei Han', Ziyu Liu', \\ Xia Jin ${ }^{2 *}$, Fanglin Zhang ${ }^{1 *}$ and Xingan Wu ${ }^{1 *}$
}

${ }^{1}$ Department of Microbiology, School of Basic Medicine, Fourth Military Medical University, Xi'an, China, ${ }^{2}$ Scientific Research Center, Shanghai Public Health Clinical Center \& Institutes of Biomedical Sciences, Key Laboratory of Medical Molecular Virology of Ministry of Education \& Health, Shanghai Medical College, Fudan University, Shanghai, China, ${ }^{3}$ Viral Disease and Vaccine Translational Research Unit, Institut Pasteur of Shanghai, Chinese Academy of Sciences, Shanghai, China, ${ }^{4}$ School of Biology and Basic Medical Sciences, Soochow University, Suzhou, China, ${ }^{5}$ Cadet Brigade, School of Basic Medicine, Fourth Military Medical University, Xi'an, China

OPEN ACCESS

Edited by:

Lu Lu,

Fudan University, China

Reviewed by:

Gong Cheng,

Tsinghua University, China

Wei Hou,

Wuhan University, China

*Correspondence:

Xia Jin

xiajin2012@outlook.com

Fanglin Zhang

flzhang@fmmu.edu.cn

Xingan Wu

wuxingan@fmmu.edu.cn

†These authors have contributed equally to this work

Specialty section:

This article was submitted to

Virology,

a section of the journal

Frontiers in Microbiology

Received: 03 October 2019

Accepted: 10 December 2019

Published: 30 January 2020

Citation:

Liu R, Ma H, Shu J, Zhang Q, Han M, Liu Z, Jin X, Zhang F and

Wu X (2020) Vaccines and

Therapeutics Against Hantaviruses.

Front. Microbiol. 10:2989.

doi: 10.3389/fmicb.2019.02989
Hantaviruses $(\mathrm{HVS})$ are rodent-transmitted viruses that can cause hantavirus cardiopulmonary syndrome (HCPS) in the Americas and hemorrhagic fever with renal syndrome (HFRS) in Eurasia. Together, these viruses have annually caused approximately 200,000 human infections worldwide in recent years, with a case fatality rate of $5-15 \%$ for HFRS and up to $40 \%$ for HCPS. There is currently no effective treatment available for either HFRS or HCPS. Only whole virus inactivated vaccines against HTNV or SEOV are licensed for use in the Republic of Korea and China, but the protective efficacies of these vaccines are uncertain. To a large extent, the immune correlates of protection against hantavirus are not known. In this review, we summarized the epidemiology, virology, and pathogenesis of four HFRS-causing viruses, HTNV, SEOV, PUUV, and DOBV, and two HCPS-causing viruses, ANDV and SNV, and then discussed the existing knowledge on vaccines and therapeutics against these diseases. We think that this information will shed light on the rational development of new vaccines and treatments.

Keywords: hantavirus, vaccine, therapeutic strategies, HFRS, HPCS

\section{INTRODUCTION}

In recent years, the repeated outbreak of hantavirus disease has caused a serious threat to human health. The spread of hantavirus from natural hosts to humans is a natural ecological process; however, the outbreak of hantavirus is driven by striped field mouse population cycle dynamics and seasonal climate change (Tian and Stenseth, 2019).

Hantavirus is a virus transmitted mainly by rodent animals, mainly through urine, feces, and saliva and the aerosols produced by them, but rarely by the bites of infected animals (Brocato and Hooper, 2019). In recent years, the infection rate of hantavirus has increased in China and Europe (Dong et al., 2019). Hantavirus disease has turned out to be a newly identified but not a "new" disease in Germany (Kruger et al., 2013). The clinical presentations may vary according to viral strains prevalence in different regions. In Asia, hantavirus infection by Hantan virus (HTNV) and Seoul virus (SEOV) targets mainly the human kidney and causes hemorrhagic fever with renal syndrome (HFRS). In North America, infection by Andes virus (ANDV) and Sin Nombre virus (SNV) manifests in mainly the lung and leads to hantavirus pulmonary syndrome (HPS) or hantavirus cardiopulmonary syndrome (HCPS), with high mortality rates; in Europe, infection by 
Puumala virus (PUUV) and Dobrava-Belgrade virus (DOBV) typically causes a milder form of HFRS, nephropathia epidemica (NE) (Echterdiek et al., 2019).

Currently, there is no approved post-exposure therapeutic countermeasure against hantaviral infection, but diversified treatment strategies have been developed and applied to manage HFRS or HCPS. These strategies target viral life cycle, host immunological factors, or patient clinical symptoms. Preventive measures against hantaviral infection, especially vaccine development, are essential for future pandemics. In this paper, we reviewed the epidemiology and pathogenesis of hantavirus, and discuss the existing knowledge on vaccine and therapeutics against these diseases in order to shed light on the development of new vaccines and treatments.

\section{THE RE-EMERGENCE OF HANTAVIRUS}

\section{The Epidemiology of HFRS and HCPS}

China has the highest incidence and mortality of HFRS in the world, accounting for more than $90 \%$ of the total number of HFRS cases in the world (Zheng et al., 2018). In 2004, the Chinese Center for Disease Control and Prevention (China CDC) established the National Notifiable Disease Surveillance System (NNDSS) online, and HFRS cases of the whole country were reported daily through this system (Zhang et al., 2014). From 2006 to 2012, a total of 77,558 cases and 866 deaths were reported with the average annual incidence rate of 0.83 per 100,000, mortality rate of 0.01 per 100,000 and case fatality rate of $1.13 \%$ (Zhang et al., 2014), and its main causative pathogens are HTNV and SEOV (Tian and Stenseth, 2019). So far, HFRS cases have been reported in 30 out of 32 provinces in China (excluding Hong Kong, Macao, and Taiwan) (Zhang et al., 2014). In recent years, the incidence is still high in eastern China (Tian et al., 2017). The distribution map of hantavirus cases reported in recent Chinese literatures is summarized in Figure 1. More than $90 \%$ of the total cases were clustered in nine provinces and mainly reported in spring and autumn-winter seasons. We can observe that the annual average number of cases in Shaanxi Province was higher than 2000, ranking at the top of the list (Figure 1). From 2006 to 2017, Shaanxi has gradually become the province with the highest incidence in China, with approximately 4.51 cases $/ 100,000$ cases, of which more than $90 \%$ are concentrated in the central region (Xi'an, Xianyang, Baoji, and Weinan cities) (Zheng et al., 2018). By November 20 of 2017, 878 people were recorded infected in Shaanxi Province (Dong et al., 2019). We also can observe that the average annual number of cases in the cities of Shannxi, Shandong, and Jiangxi Province rank the top three (Supplementary Figure 1). Another place with a high incidence of HFRS is Qingdao city of Shandong Province, where HFRS incidence is three times higher than the national average, reaching 0.83/100,000 (Jiang et al., 2017).

In the US, 34 states have confirmed and recorded HCPS cases since 1993 (Prince and Lieberman, 2013). In 2008, the first locally acquired case of HFRS caused by the SEOV was confirmed. In 2017, the US CDC investigated an outbreak of SEOV infection that has infected 17 rat owners in seven states (Kerins et al., 2018). The number of hantavirus cases by year in different states is summarized in Figure 2. In Canada, HCPS is still very rare, but cases are recorded every year and show seasonal patterns, mainly between March and May and between September and November. A total of 64 cases have been confirmed since 2000, of which 12 were reported in 2013, most in western Canadian provinces such as Alberta, Manitoba, British Columbia, and Saskatchewan (Kerins et al., 2018). SNV and ANDV are responsible for the majority of hantavirus cases leading to HCPS.

Outside North America, individual cases and small clusters of HCPS have been reported in Balkans, northern Sweden (Bergstedt Oscarsson et al., 2016), Argentina (Pini et al., 2003), Chile (Toro et al., 1998), Poland (Gut et al., 2018), Bolivia (1998), Brazil (Suzuki et al., 2004; Limongi et al., 2009), Serbia (Stanojevic et al., 2019), United Kingdom (Duggan, 2019), Panama (Bayard et al., 2004), and Germany (Ettinger et al., 2012). Overall, in Europe, the incidence of hantavirus infections has steadily increased in recent years: In 2014, a record number of 3754 infections were registered across Europe (Vaheri et al., 2013). Chile has had an average of 67 cases per year since 1995; the disease occurs mainly in spring and summer. However, between June and October 2011, there was an increase in cases and rodent populations (Toro et al., 1998). In Paraguay, an HCPS case was first found in the Chako region in 1995. A total of 56 cases were reported in 2011, and 18 cases were reported in 2012 (Padula et al., 2007). In Panama, HCPS first appeared in 1999, with an average of 12 patients per year. However, 16 cases were reported in 2012, and 14 cases were confirmed as of 21 August 2013. For the first time since 1997, Uruguay has experienced HCPS cases, with an average of nine cases per year. The first case was recorded in northern Uruguay in 2010. In Poland, the infections are caused by mainly the PUUV and DOBV serotypes. The morbidity is not high; it ranges between 0.02 and 0.14 per 100,000 cases, but some papers suggest that the data concerning Poland is underestimated (Gut et al., 2018), because the number of infections then was higher, and it was most likely the epidemic year. In the following year, 2015, there were 6 infections, and in 2016 and 2017, there were 8 and 14 cases registered, respectively. In Germany, from 2001 to 2010, the incidence increased from 0.09 to 2.47/100,000 (Ettinger et al., 2012). In United Kingdom, the virus was first identified in laboratory rats in Scotland in 1977, and all but 1 of the 15 cases of SEOV caused acute kidney injury, which were diagnosed by the Rare and Imported Pathogens Laboratory (Duggan, 2019).

\section{Hantavirus Virology}

Hantaviruses belong to the Family Hantaviridae of Bunyavirales and are a kind of enveloped single negative chain RNA virus (Abudurexiti et al., 2019). A maximum likelihood phylogenetic tree of the complete amino acid and CDS sequence of the M segment of hantaviruses was made based on the international Committee on Taxonomy of Viruses (ICTV) updated taxonomy of the order Bunyavirales in 2019 (see Figure 3). This phylogeny shows the modest genetic diversity of the virus family.

The diameter of hantavirus particles is $80-\mathrm{US} 210 \mathrm{~nm}$, and the structure is spherical or ovoid. They are composed of $20-30 \%$ 


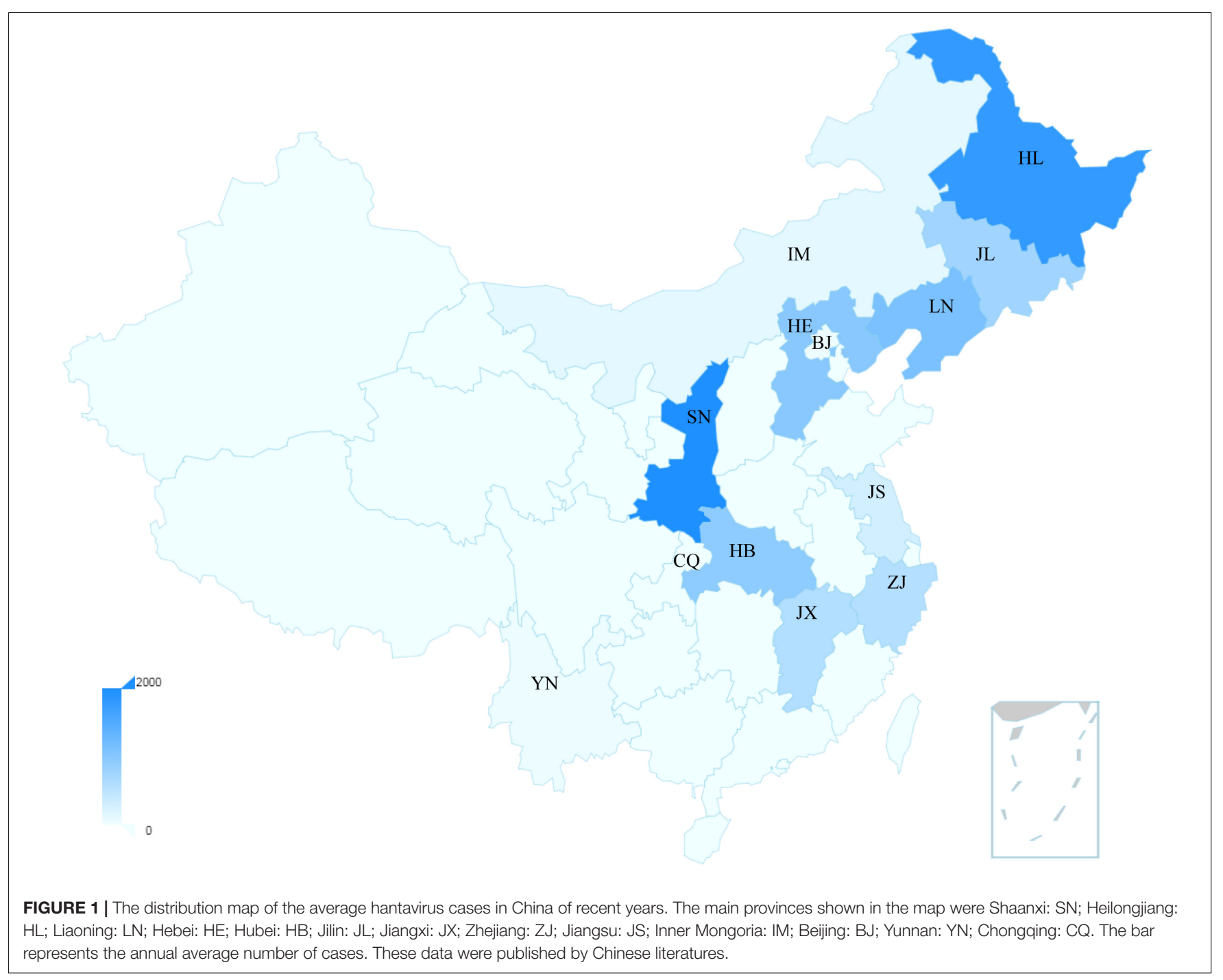

fat, $>50 \%$ protein, $7 \%$ carbohydrates, and $2 \%$ RNA. They are very stable and can survive for more than 18 days at $4^{\circ} \mathrm{C}$ and $-20^{\circ} \mathrm{C}$ and 10 days at room temperature (Vaheri et al., 2013). The genome comprises three negative sense, single-stranded RNAs that consist the small (S), medium (M), and large (L) segments that encode the nucleoprotein $(\mathrm{Np})$, envelope glycoproteins ( $\mathrm{Gn}$ and Gc), and viral RNA-dependent RNA polymerase (RdRp), respectively (Graham et al., 2019). The outer membrane of hantavirus is composed of Gn and Gc glycoprotein, which mediates the recognition of and entry into host cells. The crystal structure of HTNV Gn is very similar to that of PUUV Gn, which confirms that hantavirus $\mathrm{Gn}$ is conserved in hantavirus ( $\mathrm{Li}$ et al., 2016; Rissanen et al., 2017).

\section{CLINICAL EVALUATION OF EXISTING VACCINES}

Although there have been substantial vaccines, there is no licensed vaccine against hantavirus infection that can be widely used. Despite inactivated hantavirus vaccines being licensed for human use in China and Korea, no such vaccine has been approved in the US or Europe (Tian and Stenseth, 2019). Current clinical studies of inactivated hantavirus vaccine in China or Korea and clinical trials of DNA vaccines in the US are summarized in Table $\mathbf{1}$.

\section{Protective Efficacy of Inactivated Hantavirus Vaccines}

The inactivated vaccines comprise entire virions that are inactivated physically (heat) or chemically. In Korea, Lee and An (Cho et al., 2002) first developed an inactivated HTNV vaccine (IHV), which was prepared from the HTNV strain ROK 84/105, which proliferates in the brains of lactating mice. It has been proven that it can induce protein immunization in mice and humans (Yamanishi et al., 1988). In 1990, the Korean HFRS vaccine Hantavax was put into commercial production. The total number of HFRS patients hospitalized in South Korea fell sharply from 1234 in 1991 to 415 in 1997 (Cho et al., 2002). To evaluate 


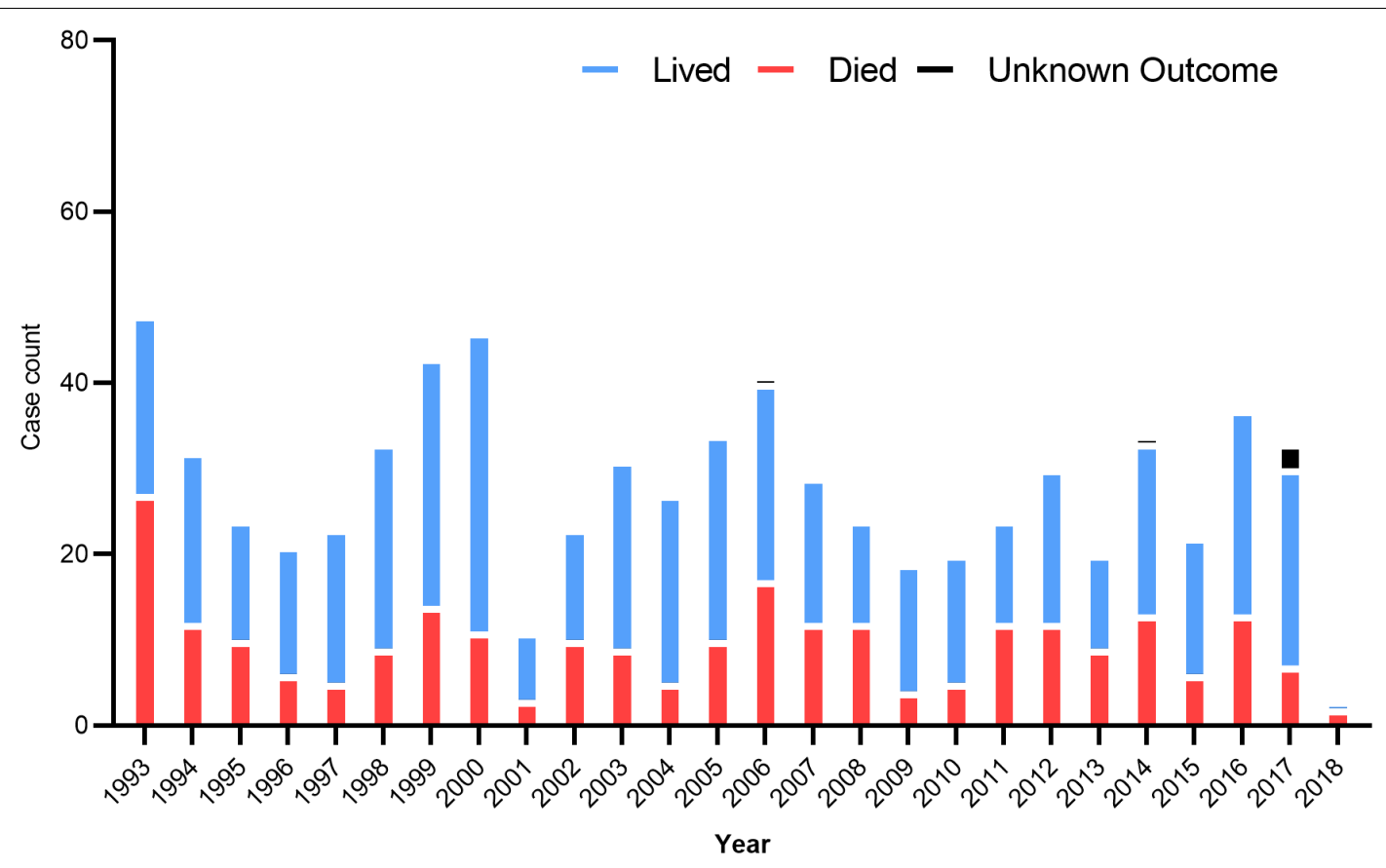

FIGURE 2 | US hantavirus cases from 1993 to 2018. These data were published by the Centers for Disease Control and Prevention, United States.

the immunogenicity and safety of Hantavax ${ }^{\mathrm{TM}}$ in healthy adults in multicenter phase III clinical trials, three dose schedules at 0 , 1 , and 13 months were used. The seroconversion rate was $90.14 \%$ by IFA but only $23.24 \%$ by PRNT50 after two primary doses. One month after vaccination, the positive rate of serum was 87.32 and $45.07 \%$ according to IFA and PRNT50, respectively. The neutralizing antibody response of the two initial doses of Hantavax $^{\mathrm{TM}}$ was very poor. Therefore, it is necessary to carry out enhanced immunization within 2-6 months to provide timely protection for high-risk groups (Song et al., 2016).

From January 2011 to February 2017, the South Korean military conducted a case-control study of 100 patients to evaluate the effect of an IHV on HFRS. The vaccine effectiveness (VE) value of the IHV was $59.1 \%$, but the VE value of HFRS highincidence area was higher (78.7\%) (Jung et al., 2018). However, in 2018, the efficacy of iHV on the progression of HFRS did not show a statistically significant protective effect. From 2009 to 2017, 18 patients inoculated with HFRS vaccine and 110 patients not vaccinated with the HFRS vaccine were recruited at Korean Army Hospital to investigate the severity (AKI) and the efficacy of dialysis events in acute renal injury. Overall, 33.3\% of the effective vaccination group had three stages of AKI, compared with $54.5 \%$ for the non-vaccinated group. The curative effect of IHV on disease progression was $58.1 \%$, but the curative effect of IHV on HFRS progress did not show a statistically significant protective effect (Yi et al., 2018).

In China, bivalent inactivated vaccines against HTNV and SEOV infection were produced in 1994 and approved by the Pharmacopoeia of China in 2005. Since 2008, the Chinese government has implemented an expanded immunization program targeting HFRS. China uses approximately 2 million doses of HFRS vaccine every year (Schmaljohn, 2012). HFRS cases have significantly dropped to less than 20,000 per year. Phase 4 clinical trials of inactivated hantavirus vaccine showed that the median OD values of IgG antibody were 0.005 (0.004-0.016), 0.116 (0.036-0.620), 0.320 (0.065-0.848), and $0.128(0.011-0.649)$, and that the positivity rate was 7.7 , $40.6,62.2$, and $48.2 \%$ at pre-vaccination, 1 month after the two primary doses, at the booster dose and at 18 months after the booster dose, respectively. Although two main doses can help healthy individuals develop immune responses, the three-dose series should be better than the two-dose series (Zheng et al., 2018). Another clinical study in Xian Yang city in northwest China showed that the positive rate of neutralizing antibody in the unvaccinated group was $10.0 \%$, and the positive rate was $80.0,90.0,50.0$, and $90 \%$, respectively, at $1,3,29$, and 33 months after immunization with a vaccine consisting of a mixture of inactivated HTNV and SEOV. This finding indicates that the vaccination program can induce effective humoral immunity in northwestern China and can be maintained up to 33 months after vaccination ( $\mathrm{Li}$ et al., 2017) (Table 1).

\section{Clinical Trials of DNA Vaccines for HFRS}

At present, DNA vaccines are the most popular method in the research of HFRS and HCPS vaccines, mainly focusing on the use of a hetero-expression system to produce recombinant $M$ protein. DNA vaccines are characterized by safety because they have replication defects, cannot restore the virulence, and cannot spread from person to person or to the environment. A variety of DNA vaccines against the hantavirus envelope glycoprotein gene were developed by Hopper's group (Schmaljohn et al., 2014). 


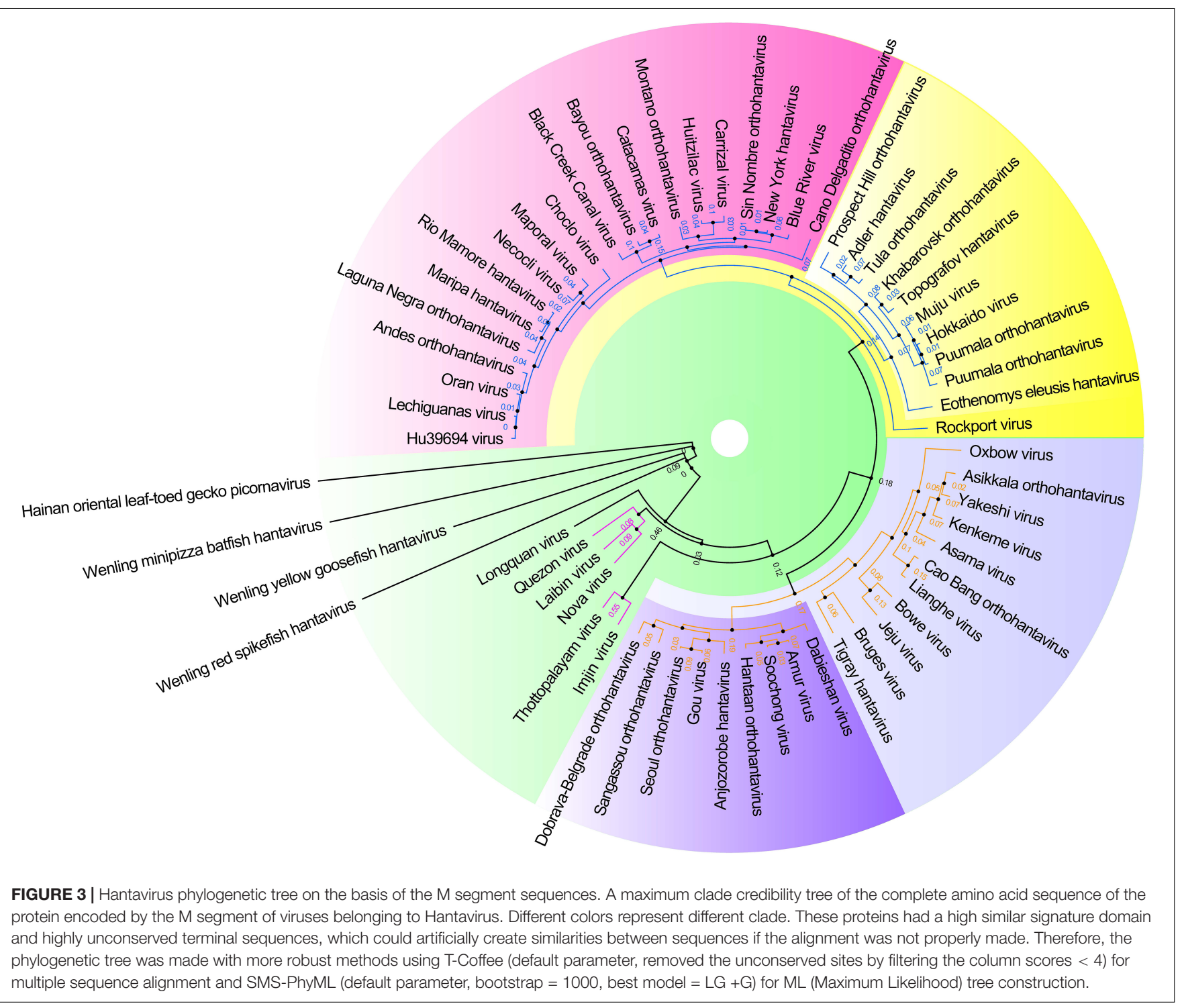

Their studies have confirmed that these DNA vaccines produce neutralizing antibodies in multiple experimental animal species and protected hamsters from HFRS (Schmaljohn et al., 2014).

Next, they developed HFRS candidate DNA vaccines expressing HTNV or PUUV Gn and GC genes and evaluated them in an open-labeled single-center phase 1 study. The results showed that HTNV and PUUV DNA vaccines prepared by electroporation were safe. When mixed together, the response to PUUV was greater than that to the HTNV DNA vaccine, and both DNA vaccines had immunogenicity (Hooper et al., 2014).

The vaccine entered phase $2 \mathrm{a}$ trial in 2014 to compare the immune responses to two different doses, 1.0 and $2.0 \mathrm{mg}$, and mixed HTNV and PUUV DNA vaccines in healthy participants. All groups also received booster doses 6 months after the first vaccination to determine which doses and vaccination plans will be the best way to advance the vaccine development process. To evaluate the safety, responsiveness and immunogenicity of an ANDV DNA vaccine to prevent HPS, the first phase I clinical trials of the ANDV DNA vaccine began in February $2019^{1}$ (Table 1).

\section{PRE-CLINICAL DEVELOPMENT OF NEW VACCINES}

\section{DNA Vaccines}

Similarly, all DNA vaccines developed against hantavirus target the $M$ gene expressing the envelope GP (Gn and Gc) of hantaviruses (Table 2, part 1).

In the United States, a variety of DNA vaccines express the envelope glycoprotein gene of hantaviruses that were developed by Hopper's group (Schmaljohn et al., 2014). In 1999, HFRS candidate naked DNA vaccine was constructed by the subcloning method. The subcloned cDNA represented the medium fragment

\footnotetext{
${ }^{1}$ www.clinicaltrials.gov
} 
TABLE 1 | Existing vaccines in clinical trials and case-control studies.

\begin{tabular}{|c|c|c|c|c|c|c|c|c|c|c|}
\hline Number & Title & Conditions & Interventions & Type & $\begin{array}{l}\text { Funder } \\
\text { Type }\end{array}$ & Age & $\begin{array}{l}\text { Number } \\
\text { Enrolled }\end{array}$ & Date & Status & References \\
\hline \multirow[t]{4}{*}{$\begin{array}{l}\text { AFMC-17082- } \\
\text { IRB-17-077 }\end{array}$} & $\begin{array}{l}\text { Effectiveness of inactivated } \\
\text { hantavirus vaccine on the } \\
\text { disease severity of } \\
\text { hemorrhagic fever with } \\
\text { renal syndrome }\end{array}$ & HFRS & Hantavax ${ }^{\circledR}$ & $\begin{array}{l}\text { Case- } \\
\text { control } \\
\text { study }\end{array}$ & Korea & $20-22$ & 129 & $\begin{array}{l}\text { March-09 } \\
\text { March-17 }\end{array}$ & Completed & Jung et al., 2018 \\
\hline & $\begin{array}{l}\text { Protective effectiveness of } \\
\text { inactivated hantavirus } \\
\text { vaccine against } \\
\text { hemorrhagic fever with } \\
\text { renal syndrome }\end{array}$ & HFRS & Hantavax ${ }^{\circledast}$ & $\begin{array}{l}\text { Case- } \\
\text { control } \\
\text { study }\end{array}$ & Korea & $20-30$ & 100 & $\begin{array}{l}\text { January-11 } \\
\text { February-17 }\end{array}$ & Completed & Yi et al., 2018 \\
\hline & $\begin{array}{l}\text { Persistence of immune } \\
\text { responses to vaccine } \\
\text { against hemorrhagic fever } \\
\text { with renal syndrome }\end{array}$ & HFRS & $\begin{array}{l}\text { Inactivated } \\
\text { hantavirus vaccine }\end{array}$ & Phase 4 & China & $16-60$ & 143 & $\begin{array}{l}\text { June-11 } \\
\text { June }-13\end{array}$ & Completed & Zheng et al., 2018 \\
\hline & $\begin{array}{l}\text { The assessment of } \\
\text { Hantaan virus-specific } \\
\text { antibody responses after } \\
\text { the immunization program } \\
\text { for hemorrhagic fever with } \\
\text { renal syndrome in } \\
\text { northwest China }\end{array}$ & HFRS & $\begin{array}{l}\text { HFRS inactivated } \\
\text { vaccine [a mixture } \\
\text { of HTNV (type I) } \\
\text { and SEOV (type II)] }\end{array}$ & $\begin{array}{l}\text { Case- } \\
\text { control } \\
\text { study }\end{array}$ & China & $16-60$ & 100 & & Completed & Li et al., 2017 \\
\hline NCT01502345 & $\begin{array}{l}\text { Study to evaluate the } \\
\text { safety, tolerability, and } \\
\text { immunogenicity of Hantaan } \\
\text { and Puumala virus DNA } \\
\text { vaccines }\end{array}$ & HFRS & $\begin{array}{l}\text { HTNV/PUUV DNA } \\
\text { vaccine/device } \\
\text { combination }\end{array}$ & Phase 1 & $\begin{array}{l}\text { U. S. Fed } \\
\text { | Industry }\end{array}$ & $18-49$ & 31 & $\begin{array}{l}\text { January-12 } \\
\text { January-13 }\end{array}$ & Completed & Hooper et al., 2014 \\
\hline NCT02116205 & $\begin{array}{l}\text { Phase 2a immunogenicity } \\
\text { study of Hantaan/Puumala } \\
\text { virus DNA vaccine for } \\
\text { prevention of hemorrhagic } \\
\text { fever }\end{array}$ & HFRS & $\begin{array}{l}\text { HTNV/PUUV DNA } \\
\text { vaccine }\end{array}$ & Phase 2a & $\begin{array}{l}\text { V. S. Fed } \\
\text { | Industry }\end{array}$ & $18-49$ & 132 & $\begin{array}{l}\text { May-14 } \\
\text { July-19 }\end{array}$ & $\begin{array}{l}\text { Active, not } \\
\text { recruiting }\end{array}$ & \\
\hline NCT03682107 & $\begin{array}{l}\text { Andes virus DNA vaccine } \\
\text { for the prevention of } \\
\text { hantavirus pulmonary } \\
\text { syndrome using the } \\
\text { PharmaJetStratis(R) } \\
\text { needle-free injection } \\
\text { delivery device }\end{array}$ & HPS & $\begin{array}{l}\text { Andes virus DNA } \\
\text { vaccine }\end{array}$ & Phase 1 & $\mathrm{NIH}$ & $18-49$ & 48 & $\begin{array}{l}\text { February-19 } \\
\text { October-19 }\end{array}$ & Recruiting & \\
\hline NCT03718130 & $\begin{array}{l}\text { Combination HTNV and } \\
\text { PUUV DNA vaccine }\end{array}$ & HFRS & $\begin{array}{l}\text { HTNV vaccine } \\
\text { PUUV vaccine } \\
\text { HTNV/PUUV virus } \\
\text { vaccines }\end{array}$ & Phase 1 & U.S. Fed & $18-49$ & 72 & $\begin{array}{l}\text { May-19 } \\
\text { May-21 }\end{array}$ & Not yet recruiting & \\
\hline
\end{tabular}


TABLE 2 | Pre-clinical development of new vaccines.

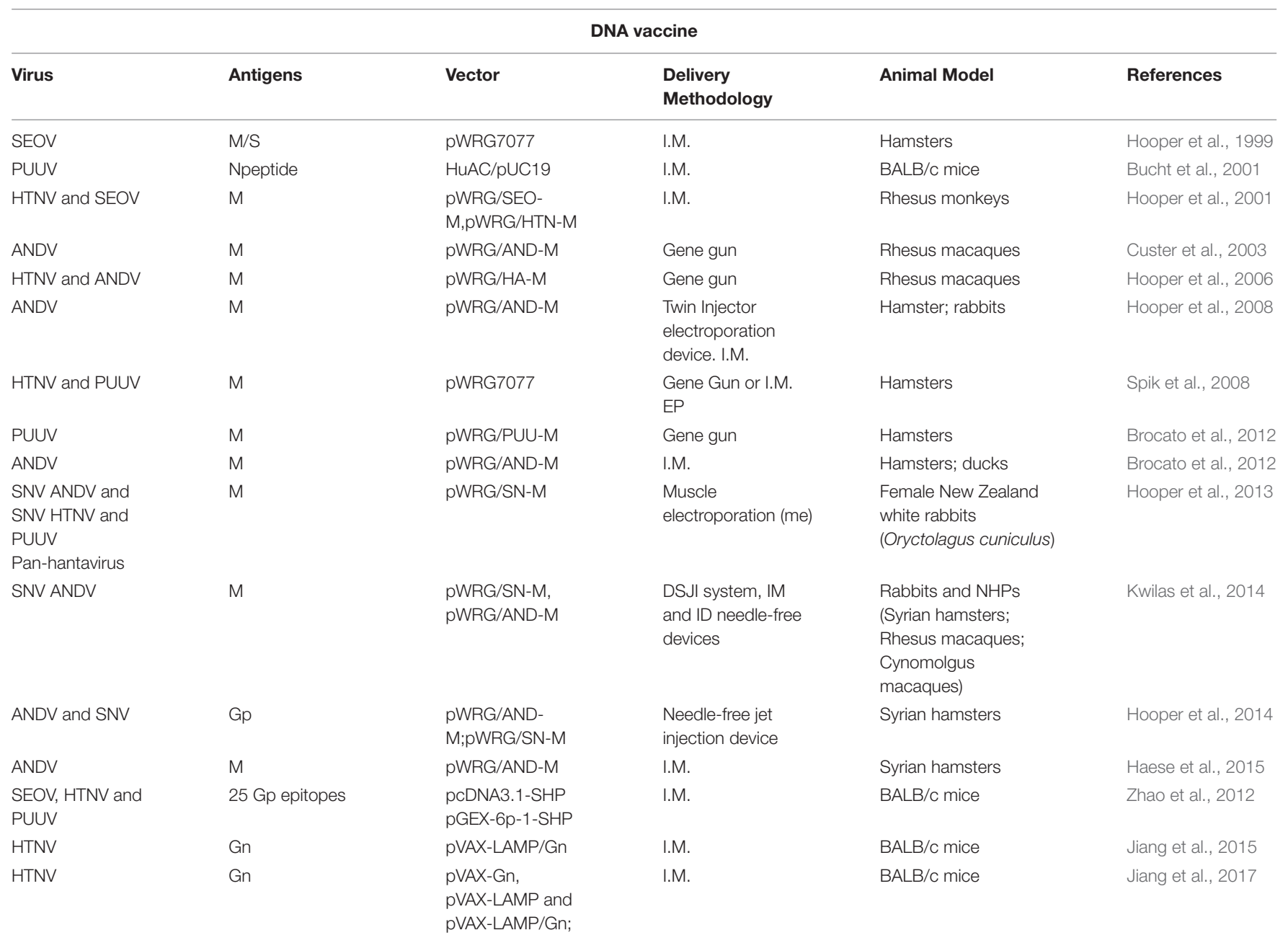

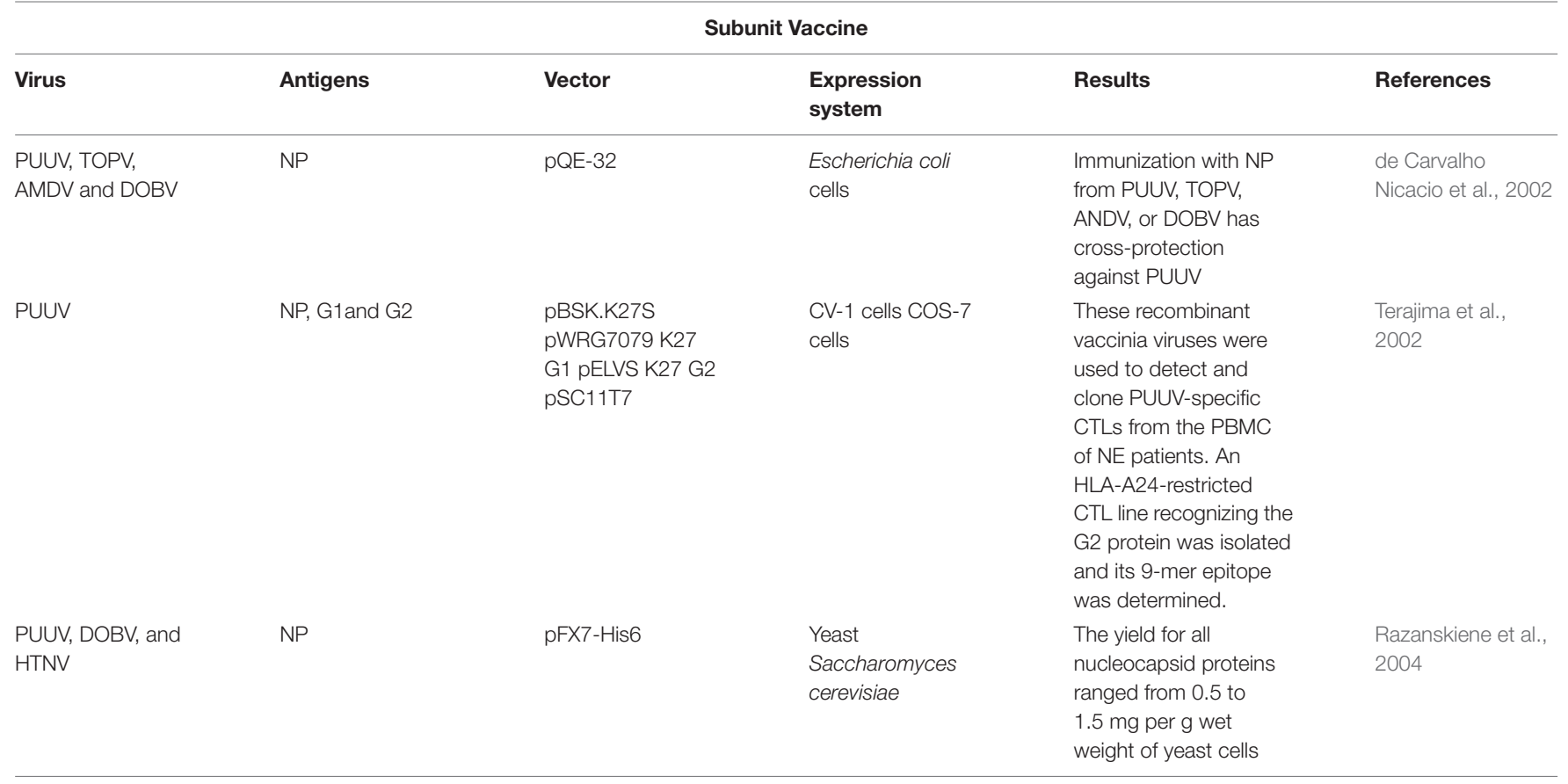


TABLE 2 | Continued

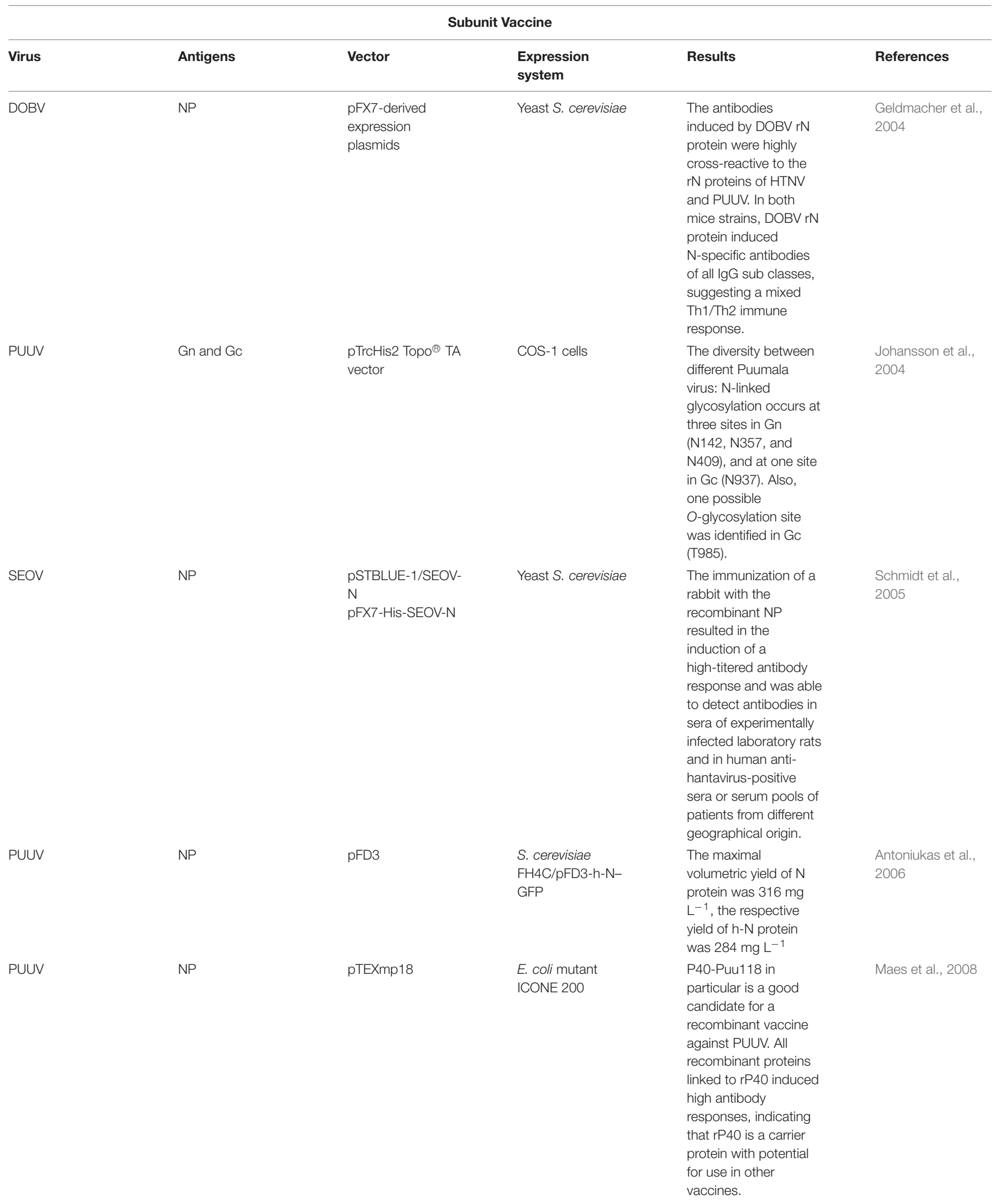


TABLE 2 | Continued

\begin{tabular}{|c|c|c|c|c|c|}
\hline \multicolumn{6}{|c|}{ VLP vaccine } \\
\hline Virus & Antigens & Vector & $\begin{array}{l}\text { Expression } \\
\text { system }\end{array}$ & Results & References \\
\hline HTNV & $M$ & $\begin{array}{l}\text { pFastBacTM Dual } \\
\text { vector }\end{array}$ & Sf9 insect cells & $\begin{array}{l}\text { Chimeric HTNV VLPS } \\
\text { containing } \\
\text { GPI-anchored GM-CSF } \\
\text { or CD4OL induced } \\
\text { stronger humoral } \\
\text { immune responses and } \\
\text { cellular immune } \\
\text { responses compared to } \\
\text { the HTNV VLPs and } \\
\text { Chinese commercial } \\
\text { inactivated hantavirus } \\
\text { vaccine. }\end{array}$ & Cheng et al., 2016 \\
\hline HTNV & $M$ & pCl-neo & $\begin{array}{l}\text { dhfr-deficient } \mathrm{CHO} \\
\text { cells }\end{array}$ & $\begin{array}{l}\text { In vitro stimulation with } \\
\text { CD40L or GM-CSF } \\
\text { anchored HTNV VLP } \\
\text { showed enhanced } \\
\text { activation of } \\
\text { macrophages and DCs. } \\
\text { In vivo, it can induce } \\
\text { higher level of HTNV } \\
\text { specific antibody and } \\
\text { neutralizing antibody in } \\
\text { mice. Immunized mice } \\
\text { splenocytes showed } \\
\text { higher ability of } \\
\text { secreting IFN- } \gamma \text { and } \\
\text { IL-2, as well as } \\
\text { enhancing CTL activity. }\end{array}$ & Ying et al., 2016 \\
\hline HTNV & $M$ & pCl-neo & $\begin{array}{l}\text { dhfr-deficient } \mathrm{CHO} \\
\text { cells }\end{array}$ & $\begin{array}{l}\text { GM-CSF and CD4OL } \\
\text { VLPs provided stable, } \\
\text { long-term protection } \\
\text { with a high titer of } \\
\text { neutralizing antibody in } \\
\text { mice } 6 \text { months after } \\
\text { immunization. } \\
\text { Furthermore, VLPS } \\
\text { increased } \\
\text { HTNV-specific cellular } \\
\text { immune responses via } \\
\text { higher expression of } \\
\text { IFN-g and CTL } \\
\text { responses. HTNV } \\
\text { challenge assay results } \\
\text { showed long-term } \\
\text { protection against } \\
\text { HFRS. No significant } \\
\text { pathological alteration } \\
\text { was observed in the } \\
\text { organs of mice after } \\
\text { immunization. }\end{array}$ & Dong et al., 2019 \\
\hline
\end{tabular}

(M; encoding G 1 and G 2 glycoprotein) or small fragment (S; encoding nucleocapsid protein) of SEOV and was cloned into the expression vector WRG 7077. Syrian hamsters were vaccinated with the $M$ or $S$ vaccine with a gene gun, and hantavirus-specific antibodies were found in 5 of 5 hamsters or 4 of 5 hamsters, respectively. Evidence of infection was monitored after challenge with SEOV. Twenty-eight days later, hamsters vaccinated with $M$ were protected hamsters from infection, but those inoculated with $S$ were not protected (Hooper et al., 1999).

Then, HTNV M gene products G 1 and G 2 were expressed in 2001, and non-human primates were evaluated. The HTNV $\mathrm{M}$ gene has protective effects against HTNV, SEOV, and DOBV in hamsters. The HTNV and ANDV $M$ genes can induce high level of neutralizing antibodies in rhesus monkeys (Hooper et al., 2001). Next, a DNA vaccine plasmid containing the 
full-length M genome fragment of ANDV (pWRG/AND-M) was constructed (Hooper et al., 2008). Rhesus monkeys inoculated with pWRG/AND-M with gene guns produced very high levels of neutralizing antibodies that neutralized not only ANDV but also other HCPS-related hantavirus strains, such as SNV. On the 4 th or 5 th day after injection, monkey serum protected $100 \%$ of hamsters from fatal diseases (Custer et al., 2003).

Then the pWRG/HA-M plasmid containing the HTNV and ANDV M gene fragments was constructed. Rhesus monkeys were immunized with the $\mathrm{pWRG} / \mathrm{HA}-\mathrm{M}$ vaccine to produce antibodies binding to $M$ gene products ( $G 1$ and $G 2$ glycoproteins) and neutralize HTNV and ANDV. Subsequently, 1-2 years after the initial vaccination series, the neutralizing antibody titers induced by the double immunogen pWRG/HA-M or a single immunogen expressing only HTNV or ANDV Gp increased rapidly to a high level. This result is the first time that the hantavirus M gene DNA vaccine has been shown to elicit a strong memory response and stimulate an antibody response to neutralize HFRS and HCPS viruses (Hooper et al., 2006; Kwilas et al., 2014) detected the high-titer neutralizing antibody induced by an SNV/ANDV DNA vaccine encoding viral envelope Gp in laboratory animals and non-human primates (NHCPS). It can be delivered effectively using a disposable syringe injection (DSJI) system (Kwilas et al., 2014). Brocato et al. (2013) cloned codon-optimized PUUV M fragments into DNA vaccine vectors to produce the plasmid pWRG/PUU-M, which can produce high-titer neutralizing antibodies in hamsters and NHCPs. The pWRG/PUU-M vaccine protects hamsters from PUUV infection and is not affected by DOBV infection. Unexpectedly, vaccination could protect hamsters in the absence of ANDV cross-neutralizing antibodies in a lethal ANDV disease model (Brocato et al., 2013). Then, the authors tried to produce the pan-hantavirus vaccine with a mixed plasmid DNA vaccine. A study of ANDV hamster model showed that the neutralizing antibody produced by DNA vaccine technology can be used to resist the challenge of an SNV full-length $\mathrm{M}$ gene DNA vaccine to prevent the occurrence of HCPS. Rabbits vaccinated with SNV DNA vaccine with muscle electroporation (mEP) produced increased neutralizing antibody titers. In addition, hamsters vaccinated three times with the SNV DNA vaccine with a gene gun were completely free from SNV infection. Rabbits were vaccinated with HCPS mixture (ANDV and SNV plasmid), HFRS mixed (HTNV and PUUV plasmid), or HCPS/HFRS mixture (all four plasmids) by mEP. The results showed that the HCPS mixture and HFRS mixture produce neutralizing antibodies against ANDV/SNV and HTNV/PUUV, respectively. In addition, a mixture of HCPS/HFRS triggered neutralizing antibodies against all four viruses (Hooper et al., 2013). Spik et al. (2008) reported that PUUV and HTNV DNA vaccines should serve as separate regulators. Both vaccines produced neutralizing antibodies when injected alone, but when they were administered as mixtures, only one of the two hantavirus antibodies could be detected. In contrast, if the DNA was administered to an animal as a separate vaccine, a reaction to both was observed. To improve the use of DNA vaccine, a multihead intradermal electroporation device was developed, which can be used to vaccinate with an increased dose of DNA vaccine to the skin.
The device will enable multiplasmid vaccine preparation to provide multiplasmid vaccine preparation without interference (Mackow et al., 2014).

In China, a DNA vaccine targeting hantavirus Gn merges the antigen with lysosome-associated membrane protein 1 (LAMP 1), thereby changing the antigen presentation pathway and activating CD4 $\mathrm{T}$ cells. The LAMP 1 targeting strategy successfully enhanced the effectiveness of the HTNV Gn vaccine. Further studies showed that pVAX-LAMP/Gn established a memory response during long-term protection (6 months) in mice. Zhao et al. constructed a multi-epitope chimeric DNA vaccine-named the SHP chimeric gene, which contains 25 glycoprotein epitopes of SEOV, HTNV, and PUUV. The humoral and cellular responses were significantly enhanced in vaccinated $\mathrm{BALB} / \mathrm{c}$ mice (Zhao et al., 2012).

\section{Subunit Vaccines}

Subunit protein vaccines not only are safe and easy to produce but also do not easily cause interference between the components of a multivalent formulation (Sun et al., 2017; Liang et al., 2018; $\mathrm{Qu}$ et al., 2018). Because the $\mathrm{N}$ protein of hantavirus circulating in different continents can provide high cross-protection in animals, the $\mathrm{N}$ protein is considered to be an important part of a wide range of reactive vaccines against hantavirus infection (de Carvalho Nicacio et al., 2002). Research has shown that recombinant nucleocapsid protein $(\mathrm{rN})$ from PUUV, TOPV, ANDV, and DOBV could induce a cross-protective immune response to PUUV. The cross-reaction to PUUV antigen was the highest in the serum of animals immunized with ANDV rN, followed by that to TOPV and DOBV rN. In a proliferation test, $\mathrm{T}$ lymphocytes immunized with heterogenic rNs were effectively recalled by PUUV $\mathrm{rN}$ in vitro, as were animal $\mathrm{T}$ lymphocytes immunized with homologous proteins (de Carvalho Nicacio et al., 2002). In addition, recombinant vaccinia virus carrying PUUV $\mathrm{N}$ or the first half of the G2 gene was constructed. Detection and cloning of PUUV-specific CTLs from PBMCs of patients with NE by recombinant PUUV vaccinia virus led to the isolation of an HLA-A24-restricted CTL cell line recognizing the $\mathrm{G} 2$ protein, and its 9-mer epitope was determined (Terajima et al., 2002). Razanskiene et al. (2004) reported that the stability and high purity of NP of PUUV, DOBV, and HTNV ranged from 0.5 to $1.5 \mathrm{mg} / \mathrm{g}$ wet weight of yeast cells. DOBV $\mathrm{rN}$ protein is a promising vaccine candidate protein that can induce $\mathrm{N}$-specific antibodies, and its terminal titer is as high as $1: 1,000,000$ in C57BL/6 mice. The antibody induced by DOBV $\mathrm{rN}$ protein has a high cross-reaction with $\mathrm{rN}$ protein of PUUV and HTNV (Geldmacher et al., 2004). It was found that there might be RNA fragment exchange between the two PUUV strains. N-linked glycosylation occurred at one site of Gn (N 142, N357, and N409) and GC (N 937), and a possible O-glycosylation site was identified in GC (T 985). The study of coding gene products is of great significance for the design of new vaccines (Johansson et al., 2004). Schmidt et al. (2005) reports that NP of SEOV reacts with SEOV-specific monoclonal antibodies and some HTNV- and PUUV cross-reactive monoclonal antibodies. Rabbits immunized with recombinant NP can induce a high-titer antibody response, and NP-specific antibodies were detected in 
the serum of experimental infected rats and human exposed to hantavirus from different geographical sources. Yeast-expressed SEOV $\mathrm{N}$ protein represents a promising antigen for serological epidemiological research and vaccine development (Schmidt et al., 2005). Antoniukas et al. (2006) reported that the biomass and the expression level of recombinant PUUV NP were increased by adding plant extract to YNB medium. The maximum volume yield of the $\mathrm{N}$ protein was $316 \mathrm{mg} \mathrm{L}^{-1}$ (Antoniukas et al., 2006) (Table 2, part 2).

\section{VLP Vaccines}

Virus-like particle vaccines are similar to natural virus particles but lack infectious genetic material. They are composed of repetitive viral structural proteins with inherent self-assembly characteristics (Yong et al., 2019). How to improve the immunogenicity of VLPs is very important. It was reported that either CD40L- or GM-CSF-contained HTNV VLP expression in sf9 insect cells (Cheng et al., 2016) or CHO cells (Ying et al., 2016) could enhance the activation of macrophages and dendritic cells. CD40L/GM-CSF incorporation into VLPs induced elevated levels of HTNV-specific antibodies and neutralizing antibodies in mice. The spleen cells of immunized mice had an enhanced ability to secrete IFN- $\gamma$ and IL-2, increasing CTL activity (Cheng et al., 2016). The GM-CSF and CD40L-containing VLPs expressed in a eukaryotic expression vector had a stable, long-term protective effect, with a high titer of neutralizing antibody, on mice within 6 months after immunization (Dong et al., 2019). These results suggest that CD40L/GM-CSF-containing VLPs can be used as a potential candidate vaccine (Table 2 , part 3 ).

\section{THERAPEUTIC STRATEGIES AGAINST HANTAVIRUS INFECTION}

Hantaviruses primarily infect host capillary endothelial cells of various organs, especially those of kidneys and lungs, and could spark robust immune response in humans. The basic pathological feature of both old world hantaviruses causing HFRS and new world hantaviruses leading to HCPS is dramatically increased vascular permeability, the pathogenesis of which is highly involved in viral infection and excessive immune responses of the host. Extensive capillary leakage results in multiple clinical manifestations, such as hypotensive shock in HFRS and noncardiogenic pulmonary edema in HCPS, which might deteriorate into multisystem organ failure. Currently, there are no approved post-exposure therapeutic countermeasures against hantaviral infection, but diversified treatment strategies, which target the viral life cycle, host immunological factors or patient clinical symptoms, have been developed and applied to manage HFRS or HCPS (see Table 3). Virus-targeting antivirals, including classical antiviral drugs, antibodies, or novel small molecules, are tested mainly to block hantavirus entry or restrain virus replication. Although several antivirals have been proven to be protective in vitro or in vivo, there still exist some problems for their clinical application. Host-targeting medicines are designed to improve vascular function or rebuild immune homeostasis, while their curative effects are still under debate. Supportive care is universally applied for HFRS or HCPS, and the specific treatments depend on clinical findings of different disease phases.

\section{Virus-Targeting Antivirals Blocking Viral Entry}

The viral entry process is composed of virus attachment or absorption on susceptible cells, penetration and subsequent uncoating, which is the first step for hantaviral life cycle. Neutralizing antibodies (NAbs) could interact with viral envelope proteins and disturb their binding with receptors on host cells, thus blocking viral attachment. During hantavirus infection, the Gn and Gc glycoproteins, but not nucleocapsid proteins (NP) are considered the major antigens in inducing NAb production (Jiang et al., 2016). High levels of NAbs could be detected in the convalescent phase of HFRS or HCPS patients, and these NAbs could protect the individual from hantaviral infection and have been used as passive immunotherapy (Manigold and Vial, 2014; Jiang et al., 2016). Presently, there are no reported clinical randomized controlled trials using NAbs in immunotherapy for HFRS or HCPS in humans. Most studies measure antibody efficacy through the focus reduction neutralization test (FRNT) and hemagglutination inhibition (HI) test at the cellular level, as well as animal experiments against lethal hantavirus challenge (sucking mice or newborn rat models for HTNV or SEOV infection and hamster models for ANDV or SNV infection) (Zhang et al., 1989; Xu et al., 2002; Manigold and Vial, 2014). For old world hantaviruses, 13 crude Fab preparations directed to the PUUV Gc protein were generated from splenic lymphocytes of a PUUV-immune individual and exhibited type-specific neutralization of PUUV, with a $44-54 \%$ reduction in FRNT (de Carvalho Nicacio et al., 2000). Anti-SR-11 (SEOV) rat serum applied $4 \mathrm{~h}$ before or $72 \mathrm{~h}$ after the challenge could protect against lethal SR-11 (SEOV) infection in newborn rats, and cross-protection effects were also found against KI-262 (SEOV) and 76-118 (HTNV) (Zhang et al., 1989). In China, 18 murine monoclonal antibodies (MAbs) targeting HTNV were prepared in our lab, among which 14 targeted NP, 4 reacted with Gc, and 1 recognized both NP and Gc. The Gc-related MAbs were active in the $\mathrm{HI}$ test and displayed high virus-neutralizing activity in vitro, and they could be regarded as HTNV NAbs. Consistently, administration of these NAbs within 48 hpi could protect suckling mice from lethal HTNV infection, indicating that NAbs might be a potentially treatment strategy for preexposure prophylaxis and postexposure therapy against HTNV infection (Xu et al., 2002). Phase I clinical pharmacology and toxicity tests for HTNV NAbs in healthy volunteers were performed, and phase II clinical trials to assess the therapeutic efficacy of these NAbs in early stages of HFRS were carried out in endemic settings in China (Xu et al., 2002, 2009). For new world hantaviruses, passive immunization with either patient-derived or vaccine-induced NAbs was capable of protecting against lethal ANDV challenge in hamsters (Manigold and Vial, 2014). A non-randomized multicenter trial using plasma from HCPS convalescent patients for the treatment of acute HCPS has been carried out in Chile, showing that plasma containing high titers of NAbs against ANDV could significantly reduce case fatality rate from 32 to 
TABLE 3 | Potential therapeutic strategies for hantaviral infection.

\begin{tabular}{|c|c|c|c|c|c|c|}
\hline Purpose & Drugs & Type & Known/ Putative target & Virus/Evidence & Diseases & References \\
\hline \multirow[t]{12}{*}{ Blocking Viral Entry } & MAb Fab 4G2 and $1 \mathrm{C} 9$ & $\begin{array}{l}\text { Human MAbs Fab } \\
\text { fragments }\end{array}$ & Gc glycoprotein & PUUV/ Vero E6 cells & HFRS & $\begin{array}{l}\text { de Carvalho Nicacio et al., } \\
2000\end{array}$ \\
\hline & Anti-SR rat serum & Rat PAbs & Viral GP & SEOV/ newborn rats & & Zhang et al., 1989 \\
\hline & 3D8, 3G1, 8G3, 8F8, 8G2 & Mice MAbs & Gc, or both NP and Gc & $\begin{array}{l}\text { HTNV/Nero E6 cells/suckling } \\
\text { mice/phase II clinical trials }\end{array}$ & & Xu et al., 2002, 2009 \\
\hline & $\begin{array}{l}\text { Patient-derived or } \\
\text { vaccine-induced NAbs }\end{array}$ & Human PAbs & Viral GP & ANDV/hamsters & HCPS & Manigold and Vial, 2014 \\
\hline & Human immune plasma & Human PAbs & Viral GP & ANDV/clinical trials & & Vial et al., 2015 \\
\hline & $\lg Y / \lg Y \Delta \mathrm{Fc}$ & Goose PAbs & Viral GP & ANDV/hamsters & & Haese et al., 2015 \\
\hline & JL16 and MIB22 & Human MAbs & Viral GP & ANDV/hamsters & & Garrido et al., 2018 \\
\hline & Lactoferin & Lactoferin & Viral GP/monocyte and NK & $\begin{array}{l}\text { SEOV/Vero E6 cell/suckling } \\
\text { mice }\end{array}$ & HFRS & Murphy et al., 2000, 2001 \\
\hline & Domain III and stem peptides & Peptides & Gc glycoprotein & ANDV, PUUVNero E6 cells & HCPS and HFRS & Barriga et al., 2016 \\
\hline & $\begin{array}{l}\text { CLVRNLAWC and } \\
\text { CQATTARNC }\end{array}$ & Cyclic nonapeptides & Host receptor & SNV, ANDVNero E6 cells & HCPS & Hall et al., 2008 \\
\hline & $\begin{array}{l}\text { 012-0652, C481-1256 and } \\
\text { G319-0078 }\end{array}$ & Peptidomimetic compounds & Host receptor & $\begin{array}{l}\text { SNV, ANDV, HTNV/Nero E6 } \\
\text { cells }\end{array}$ & HCPS and HFRS & Hall et al., 2010 \\
\hline & Favipiravir & Pyrazine derivative & $\mathrm{RdRp}$ & $\begin{array}{l}\text { SNV, ANDVNero E6 } \\
\text { cells/hamsters }\end{array}$ & HCPS & Safronetz et al., 2013 \\
\hline \multirow[t]{6}{*}{ Inhibiting Viral Replication } & Ribavirin & $\begin{array}{l}\text { Nucleoside analogs/ } \\
\text { mutagen/ } T \text { cell }\end{array}$ & $\operatorname{RdRp}$ & $\begin{array}{l}\text { HTNV, PUUV, ANDVNero E6 } \\
\text { cells/suckling mice } \\
\text { (HTNV)/hamsters (ANDV) }\end{array}$ & HCPS and HFRS & $\begin{array}{l}\text { Mertz et al., 2004; Safronetz } \\
\text { et al., 2011; Kobayashi et al., } \\
\text { 2012; Chung et al., 2013; } \\
\text { Ogg et al., 2013; Westover } \\
\text { et al., 2016; Malinin and } \\
\text { Platonov, } 2017\end{array}$ \\
\hline & ETAR & Nucleoside analogs & $\mathrm{RdRp}$ & $\begin{array}{l}\text { HTNV, ANDV/ Vero E6 } \\
\text { cells/suckling mice (HTNV) }\end{array}$ & HCPS and HFRS & Chung et al., 2008 \\
\hline & K31, K34 and 103772 & Small molecules & Viral RNA-NP interaction & SNV, ANDV/Vero E6 cells & HCPS & Salim et al., 2016 \\
\hline & Arbidol & Small molecules & Unclear & $\begin{array}{l}\text { HTNVNero E6 cells/suckling } \\
\text { mice }\end{array}$ & HFRS & Deng et al., 2009 \\
\hline & siRNA & Small interfering RNA & $\mathrm{S}, \mathrm{M}$, and $\mathrm{L}$ segments & ANDV/Nero E6 cells & HCPS & Chiang et al., 2014 \\
\hline & siRNA and 3G1-Ск-tP & $\begin{array}{l}\text { Small interfering RNA and } \\
\text { Abs }\end{array}$ & $\mathrm{S}, \mathrm{M}$, and $\mathrm{L}$ segments & $\begin{array}{l}\text { HTNVNero E6 cells/suckling } \\
\text { mice }\end{array}$ & HFRS & Yang et al., 2017 \\
\hline \multirow[t]{4}{*}{ Improving Vascular Function } & $\begin{array}{l}\text { Pazopanib, dasatinib, PP1, } \\
\text { bosutinib, and Src inhibitor } 1\end{array}$ & $\begin{array}{l}\text { VEGFR2 kinase inhibitor or } \\
\text { SFK inhibitor }\end{array}$ & Vascular function/VEGF & ANDV/HUVECs & HCPS & Gorbunova et al., 2011 \\
\hline & Vandetanib & Tyrosine-kinase inhibitor & Vascular function/VEGF & ANDV/HUVECs/ hamsters & HCPS & Bird et al., 2016 \\
\hline & Ang-1 and S1P & Compounds & Vascular function & HTNV, ANDV, NY-1/HUVECs & HCPS and HFRS & Gavrilovskaya et al., 2008 \\
\hline & Icatibant & Small molecules & BK type 2 receptor & PUUV/clinical case report & HFRS & $\begin{array}{l}\text { Antonen et al., 2013; Laine } \\
\text { et al., } 2015\end{array}$ \\
\hline \multirow{2}{*}{$\begin{array}{l}\text { Rebuilding Immune } \\
\text { Homeostasis }\end{array}$} & Clofilium phosphate & Compounds & Alveolar macrophages & ANDV/hamsters & HCPS & Hammerbeck et al., 2016 \\
\hline & $\begin{array}{l}\text { Corticoids or } \\
\text { methylprednisolone }\end{array}$ & Hormone & Immunotherapy & HTNV, ANDV/clinical trials & HCPS and HFRS & $\begin{array}{l}\text { Vial et al., 2013; Brocato and } \\
\text { Hooper, } 2019\end{array}$ \\
\hline
\end{tabular}


$14 \%$ (Vial et al., 2015). Considering the limited availability of convalescent plasma from HCPS survivors, goose polyclonal antibodies were acquired from ANDV DNA vaccine, and the purified IgY/IgY $\Delta \mathrm{Fc}$ from egg yolks could protect hamsters from lethal ANDV infection. Recently, two NAbs, JL16 and MIB22, were developed from the ANDV GP-specific memory B cells of convalescent HCPS patients, both of which reached in a $100 \%$ protection rate against lethal ANDV challenge (Garrido et al., 2018). Although NAbs from convalescent patient or immunized animals could obviously restrain hantaviral infection and improve disease outcome, purified human or humanized NAbs against hantaviruses with increased security and efficacy should be developed for clinical experiments. Additionally, research on broadly neutralizing antibodies against hantaviruses is still lacking.

Hantaviral attachment or absorption could also be restrained by lactoferin (LF), an iron-binding glycoprotein that was reported to have broad antibacterial, antifungal, and antiviral activities. LF-pretreated Vero E6 cells showed a reduced number of SR-11 (SEOV) foci, while its antiviral effects were obviously compromised if the LF-pretreated cell monolayer was washed before SEOV infection (Murphy et al., 2000). Further, LF could suppress viral shedding within $24 \mathrm{hpi}$, the effectiveness of which failed after 48 hpi (Murphy et al., 2001). These results indicated that LF might adhere to cell surface and inhibit SEOV adsorption to host cells. Intriguingly, although LF could not inhibit the expression of NP and Gc, once hantaviral amplification was established in cells, LF contributed to higher survival rates, which might be due to LF-enhanced cytocidal function of natural killer (NK) cells (Murphy et al., 2001). Even so, the specific mechanisms of how LF inhibits SEOV absorption and influences host immune responses, as well as the effects of LF on other species of hantaviruses, remain obscure.

Hantaviral fusion with cell membrane facilitates its entry process. The Hantavirus Gc envelope glycoprotein acts as a viral fusion protein that is essential for viral entry. It has been demonstrated that Gc shares similar features with class II fusion proteins, which means that three domains of viral fusion proteins are connected by a stem region anchoring in the viral envelope (Cifuentes-Munoz et al., 2011). Exogenous protein fragments containing fusion protein domain III (DIII) and the stem region could bind to the core of the fusion protein and interfere with its conformation transition, inhibiting the membrane fusion process. Based on this effect, soluble recombinant peptides that mimic DIII and the stem region were prepared, and were proven to block both ANDV and PUUV infection in Vero E6 cells by blocking membrane fusion (Barriga et al., 2016). The strategy using viral Gc DIII and stem fragments to suppress fusion might be feasible for other hantaviruses, while the protective effects in vivo still need further studies to confirm.

Furthermore, antivirals targeting hantaviral receptors have been synthesized. It has been demonstrated that pathogenic hantaviruses attach to the cell surface via host-specific $\alpha_{\text {IIb }} \beta_{3}$ or $\alpha_{\mathrm{v}} \beta_{3}$ integrins while non-pathogenic hantaviruses initiate cellular entry relying on $\alpha_{v} \beta_{1}$ integrins (Jiang et al., 2016). Based on the structure of cyclic peptides known to bind the $\alpha_{\mathrm{v}} \beta_{3}$ receptor, a few of cyclic peptides or small molecules were designed and screened for their antihantaviral function. The cyclic nonapeptides CLVRNLAWC and CQATTARNC could inhibit SNV and ANDV infection in vitro (Hall et al., 2008). After two rounds of biological screening, the peptidomimetic compounds 8012-0652, C481-1256, and G3190078 were screened out with potency in the nanomolar range against infection of a panel of hantaviruses, including SNV, ANDV, and HTNV (Hall et al., 2010). Further studies should be performed to evaluate the safety and efficacy of these small molecules in vivo.

\section{Inhibiting Viral Replication}

Viral proteins are the working molecules for viral biosynthesis, among which RdRp plays an important role in hantaviral transcription and replication and is considered a desirable drug target. The pyrazine derivative Favipiravir and the nucleoside analogs Ribavirin (RBV) and ETAR have been tested effective antihantaviral drugs that directly or indirectly affect the biological function of RdRp. Favipiravir (Avigan; T-705) was initially discovered in 2002 as an antiviral drug selectively inhibiting the RdRp of influenza virus and then reported to have a high activity against a panel of Bunyaviruses (Gowen et al., 2007; Westover et al., 2016). Favipiravir could attenuate the viral RNA replication level and decrease the progeny virus yield of $\mathrm{SNV}$ and ANDV in vitro. In vivo studies, including non-lethal SNV challenged and lethal ANDV challenged hamster model, demonstrated that oral administration favipiravir at the dosage of $100 \mathrm{mg} / \mathrm{kg}$ twice daily could prominently reduce viral load in hamster serum and various organs and resulted in 100\% survival in the ANDV lethal infection model (Safronetz et al., 2013). Delayed favipiravir administration after the onset of viremia exerted no protective effects against ANDV infection. Notably, there is no reported clinical trial with favipiravir as an antiviral treatment in HFRS and HCPS.

RBV and ETAR are nucleoside analogs that interfere with viral replication. They can inhibit inosine monophosphate dehydrogenase and reduce the synthesis GTP de novo, hence affecting the function of viral RdRp. As a potent mutagen, RBV could induce RNA mutagenesis in subsequent generations of HTNV virions (Chung et al., 2013), while it is not expected that ETAR induces mutation, probably due to the lack of pseudobase pair presence (Chung et al., 2008). Additionally, RBV was reported to modulate host immune responses by suppressing interleukin-10-producing regulatory $\mathrm{T}$ cells (Kobayashi et al., 2012), while there is no evidence showing that ETAR could exert immunoregulatory effects (Szabo, 2017). Both in vitro and in vivo antihantaviral activity of RBV and ETAR have been confirmed by a series of studies. For HFRS therapy, RBV-treated suckling mice had a higher survival rate upon HTNV infection than the placebo control group (Huggins et al., 1986). In China, a double-blind placebo-controlled clinical trial enrolled 242 HFRS patients caused by HTNV infection. The result showed that postexposure administration of RBV could decrease mortality by sevenfold and reduce the risk of entering the oliguric phase, suggesting that RBV is effective against HTNV-induced HFRS (Huggins et al., 1991). However, a clinical trial for HFRS caused by PUUV infection in Russia showed that RBV could 
not improve patient condition, especially reducing viral load, and that RBV could increase the occurrence of side effects of RBV, including rash, sinus bradycardia, hyperbilirubinemia, and reduced hemoglobin. These data suggested insufficient efficacy and safety of RBV in the treatment of HFRS caused by PUUV (Malinin and Platonov, 2017). For HCPS treatment, two studies confirmed that RBV could protect hamsters from lethally intraperitoneal or intranasal ANDV challenge without toxicity, and even abbreviated treatment regimens from 7 days to 3 days worked if therapy commenced 1 day following virus challenge (Safronetz et al., 2011; Ogg et al., 2013). Unfortunately, two clinical trials for the treatment of HCPS using RBV did not show any improvement in survival rates compared with those for patients during the same time frame or receiving placebo treatment. It is speculated that RBV treatment might be ineffective once HCPS progresses to the cardiopulmonary phase. ETAR showed an EC(50) value of 10 and $4.4 \mu \mathrm{mol} / \mathrm{L}$ for HTNV and ANDV in Vero E6 cells, respectively, which is much lower than its toxic dosage of $880 \mu \mathrm{mol} / \mathrm{L}$ (Chung et al., 2008). Moreover, ETAR administration in sucking mice with a dosage of 12.5 or $25 \mathrm{mg} / \mathrm{kg}$ at 10 days post HTNV infection could significantly increase the survival rate from 10 to $25 \%$, an effect equal to that of RBV (Chung et al., 2008). To date, there were no studies on the antiviral activity of ETAR on other hantaviruses.

Hantaviral NP could bind to an evolutionary conserved sequence at the $5^{\prime}$ terminus of hantaviral genomic RNA. The interaction of NP with the viral genome could protect viral RNA from host recognition and degradation, facilitate the $\mathrm{N}$-mediated viral RNA translation process, and help package the viral genome into nucleocapsids. Several compounds, namely, lead inhibitor $\mathrm{K} 31, \mathrm{~K} 34$, and 103772, were reported to interrupt the NPRNA interaction against SNV and ANDV infection. They could abrogate both viral RNA synthesis and translation without affecting the normal biological process of host cells, among which K31 showed antiviral activity similar to that of RBV (Salim et al., 2016). However, K31 failed to affect the replication of HIV or adenovirus, demonstrating its selectivity for hantaviruses. Arbidol, an immunomodulator developed in Russia, was also found to protect against HTNV infection both in vivo and in vitro (Deng et al., 2009).

Targeting viral RNAs is the most direct and effective way to curb hantaviral replication. Small interfering RNA (siRNA) directed against hantaviral genes could facilitate viral RNA clearance based on the RNA interfering (RNAi) mechanisms and has been tested as a potential antiviral strategy in vitro and in vivo. It has been demonstrated that siRNAs targeting the S, M, or L segment of ANDV could reduce viral replication in Vero E6 cells or human lung microvascular endothelial cells and that an S-targeted siRNA pool seemed to be more efficient in reducing viral transcription and replication than M- or L-targeted siRNA in Vero E6 cells. Importantly, these siRNAs could inhibit ANDV replication even if given after infection (Chiang et al., 2014). Although siRNAs could effectively suppress hantavirus amplification in host cells most likely through promoting viral RNA clearance, their antiviral activity might be greatly compromised considering their poor biological stability and targeting ability in vivo. One strategy is to combine
siRNAs targeting encoding sequences of HTNV genome with recombinant antibodies (3G1-Cк-tP) recognizing HTNV Gc, which were applied by intraperitoneal injection in an HTNVinduced encephalitis mouse model. The result indicated that through combination, siRNAs could be specifically delivered to the HTNV-infected brain cells and protect against HTNV intracranial infection (Yang et al., 2017). On all accounts, novel delivery system should be developed to ensure the stability and selectivity of siRNAs, and the efficacy and safety of these systems remained unclear for the treatment of HFRS or HCPS.

\section{Host-Targeting Medicines Improving Vascular Function}

Increased capillary leakage due to hantaviral infection is the basic pathogenic feature for both HFRS and HCPS. Therefore, treatment strategies improving microvascular endothelial cell function seem to be feasible in mitigating disease severity and reducing mortality (Alkharsah, 2018). Hantavirus-disturbed vascular function is a multifactorial event whose complicated mechanisms still need to be elucidated, and two kinds of hypothesis have been developed. The vascular endothelial growth factor (VEGF) theory was first proposed and studied in depth. VEGF binding to VEGF receptor 2 (VEGFR2) could activate SFK (Src family kinases) signaling, which may result in dissociation, internalization, and degradation of VEcadherin. Altered expression and localization of VE-cadherin contributed to impaired barrier structure of adherent junctions, which could lead to incremental cellular permeability (Jiang et al., 2016). It has been demonstrated HTNV or ANDV infection could disrupt the interaction of $\beta 3$ integrin with VEGFR2 and induce VEGFR2 hyper phosphorylation, which may enhance the permeability of infected endothelial cells by sensitizing them to VEGF (Gavrilovskaya et al., 2012; Wang et al., 2012). As increased VEGF content has been noted in the plasma of HFRS and HCPS patients and is closely related to disease severity in the acute phase (Bird et al., 2016; Pal et al., 2018), it is feasible to repurpose those FDA-approved drugs targeting vasoactive mediators for use as hantaviral infection therapy. In line with this strategy, one study reported that the VEGFR2 kinase inhibitor, as well as SFK inhibitors, could obviously stabilize ANDV-induced endovascular permeability, among which the SFK inhibitors dasatinib and pazopanib blocked VE-cadherin dissociation by more 90\% (Gorbunova et al., 2011). Another study also indicated that application of vandetanib, a tyrosine-kinase inhibitor preventing VEGFR2 phosphorylation, before ANDV infection could delay animal lethality and increase total survival by $23 \%$ in ANDV-challenged hamsters (Bird et al., 2016). In contrast, similar small molecules administered after the onset of viremia failed to protect hamsters from lethal ANDV challenge (Brocato and Hooper, 2019). Moreover, some other small molecules, such as angiopoietin 1 (Ang-1) and sphingosine 1-phosphate (S1P), were found to inhibit hantavirus-directed endothelial cell permeability in vitro (Gavrilovskaya et al., 2008), while further research in vivo should be performed to confirm their efficacy. 
Another promising theory is increased activation of the kinin-kallikrein system (KKS) during hantavirus infection. One study using a model with co-cultured endothelial and vascular smooth muscle cells demonstrated that activation of KKS and subsequent liberation of bradykinin (BK), but not VEGF, were mainly responsible for the dramatic increase in endothelial cell permeability after hantavirus infection (Taylor et al., 2013). BK, a nonapeptide that binds BK type 2 receptor, could induce blood vessel dilatation and vascular permeability increase, resulting in collapsed blood pressure. Icatibant is a peptidomimetic drug that can block the interaction of BK with the BK type 2 receptor by binding to this receptor itself. One case reported that a 37-yearold male who once underwent splenectomy due to congenital spherocytosis manifested with severe capillary leakage syndrome caused by PUUV infection. With a single dose of icatibant, the condition of the patient stabilized, followed by gradual improvement and full recovery (Antonen et al., 2013). Another case report also confirmed the efficient treatment of icatibant in a 67-year-old female HFRS patient (Laine et al., 2015). These clinical data indicated that BK receptor antagonist might be a novel treatment strategy for hantavirus diseases. Nevertheless, it should also be noted that the foresaid two patients had spleen abnormalities, which might be related to the curative effect of icatibant. Clinical trials enrolling a large number of HFRS or HCPS patients should be performed to further identify the remedy effects of bradykinin receptor antagonists.

\section{Rebuilding Immune Homeostasis}

It is wildly accepted that HFRS and HCPS are caused by uncontrolled systemic inflammatory responses, in which multiple inflammatory cytokines, especially TNF- $\alpha$, IL- 8 , and RANTES, contributed to disease progression (Manigold and Vial, 2014; Schonrich and Raftery, 2017); however, immunoregulation treatment in HFRS or HCPS is undesirable. A recent study with depletion of alveolar macrophages, which are considered the main resource for proinflammatory responses, could not prevent ANDV-caused pathogenesis in hamsters (Hammerbeck et al., 2016). The immunomodulatory treatment of corticoids was firstly performed during the Korean war, but the case fatality rate was not improved (Sayer et al., 1955). In Chile, a retrospective analysis suggested that a high dose of methylprednisolone could reduce mortality in 22 HCPS patients (Brocato and Hooper, 2019). However, a double-blind clinical trial in Chile failed to observe a significantly improved outcome between methylprednisolone recipients and placebo recipients for HCPS. Similarly, another randomized prospective study did not show any benefit from corticosteroid treatment in HFRS patients (Qian et al., 1990).

\section{Supportive Care}

The initiation of careful observation and prompt but judicious supportive treatment is crucial to improve patient survival condition for both HFRS and HCPS (Sargianou et al., 2012). It has been demonstrated that admission to the ICU and supportive treatment could greatly reduce the mortality rate of HFRS (Huggins et al., 1991). In general, the treatment principle for HFRS patients is using intravenous hydration and electrolyte therapy to maintain physiological blood pressure. Platelet transfusions can be applied to reduce the mortality in patients with severe thrombocytopenia. Intermittent hemodialysis (IHD) is the first choice to improve uremia condition and rectify kidney dysfunction in patients with acute kidney injury. Continuous renal replacement therapy (CRRT) should be applied for those critical HFRS patients, especially when they have a complication, such as multi-organ injury pulmonary edema, or cerebropathy (Jiang et al., 2016). Treatment of patients with HCPS should also be performed in the ICU with continuous cardiac monitoring and respiratory support. The palliative treatments for HCPS usually include mechanical ventilation, extracorporeal membrane oxygenation, and hemofiltration (Sargianou et al., 2012).

\section{DISCUSSION}

HFRS and HCPS caused by hantavirus infection are reemerging infectious diseases that greatly threaten global public health. At present, there are currently no US FDA-approved treatments or vaccines available; only the whole virus-inactivated vaccine against HTNV or SEOV is available in China and Korea. With the implementation of intervention measures, the incidence of hantavirus infections seems to have shown a decline in recent years. In China and Korea, the number of HFRS cases has been drastically reduced. But the vaccines elicit suboptimal immune responses, confer inadequate protection, and may cause safety concerns. In 2017, the recurrence of global outbreak of HFRS has drawn renewed attention to this old disease, which seriously threatens human health. HFRS in China was still a natural focal disease with relatively high morbidity and fatality, and its distribution and epidemic trends had also changed. Surveillance measures, together with prevention and control strategies, should be improved and strengthened to reduce HFRS infection in China. Therefore, the best solution is to develop a functional vaccine to prevent hantavirus infection. Among the three types of vaccines discussed above, only DNA vaccine candidates have progressed to clinical trials. Subunit protein vaccines not only are safe and easy to produce but also do not easily cause interference between the components of a multivalent formulation (Sun et al., 2017; Liang et al., 2018; $\mathrm{Qu}$ et al., 2018). To resolve the above problems, we propose to construct a universal genetic engineering novel subunit protein vaccine against HTNV and SEOV by combining bioinformatics methods, viral surface protein structure biology knowledge, and molecular biology tools.

Antiviral treatment only works when applied during the early infection stage, possibly because uncontrolled immune responses occur and predominate the pathogenesis process post-acute infection. Immunomodulatory therapy hardly improves the patient survival rate, possibly because suppressed inflammatory responses inhibit prompt viral clearance and enhance virus-caused injury increase. Therefore, based on rapid supportive care, effectively combining antiviral treatment and immunomodulatory therapy is a potential strategy for HFRS and HPS. 3G1 and 3D8, the mice MAbs against HTNV developed 
by our team, have been used for HFRS treatment and the result indicated that application of 3G1 and 3D8 at early stage of disease could significantly improve the patient condition and increase survival rates, especially for those severe or critical HFRS patients (data unpublished). Hence, NAbs might be the most promising treatment for HFRS or HPS, and the effective humanized neutralizing antibodies should be further developed.

Moreover, it is universally acknowledged that type I IFN responses are essential for hosts to defend against hantaviral infection. Multiple IFN stimulated genes (ISG) were confirmed to have antihantaviral activity. The interferon-induced MxA protein, a GTPase with extensive antiviral activity, notably against influenza viruses, was reported to inhibit HTNV and PUUV replication in Vero cells (Frese et al., 1996). The interferoninduced IFITM3 protein was able to inhibit HTNV infection in both HUVEC and A549 cells by inhibiting virus entry (XuYang et al., 2016). Several studies have shown that pretreatment with type I IFN could effectively inhibit hantaviral infection. Pretreating endothelial cells (ECs) with IFN $\alpha$ blocks hantavirus replication, and this inhibitory effect is still observed when IFN $\alpha$ is added to ECs within $12 \mathrm{hpi}$; however, the addition of IFN $\alpha$ 15-24 h after infection had little effect on hantavirus replication. Clinical data indicated that IFN treatment is only effective prophylactically or shortly after hantavirus infection. In fact, during the natural infection process, compared with nonpathogenic hantaviruses, pathogenic hantaviruses could inhibit host IFN production at an early infection stage, but the specific mechanism remains ambiguous. Our team recently found that HTNV could induce complete autophagy at an early phase, which promotes host MAVS degradation and disturbs RIGI-MAVS signaling-mediated IFN production. The application of autophagy inhibitors, including 3-MA and CQ, could

\section{REFERENCES}

Abudurexiti, A., Adkins, S., Alioto, D., Alkhovsky, S. V., Avsic-Zupanc, T., Ballinger, M. J., et al. (2019). Taxonomy of the order Bunyavirales: update 2019. Arch. Virol. 164, 1949-1965. doi: 10.1007/s00705-019-04253-6

Alkharsah, K. R. (2018). VEGF upregulation in viral infections and its possible therapeutic implications. Int. J. Mol. Sci. 19:E1642. doi: 10.3390/ijms1906 1642

Antonen, J., Leppanen, I., Tenhunen, J., Arvola, P., Makela, S., Vaheri, A., et al. (2013). A severe case of Puumala hantavirus infection successfully treated with bradykinin receptor antagonist icatibant. Scand. J. Infect. Dis. 45, 494-496. doi: 10.3109/00365548.2012.755268

Antoniukas, L., Grammel, H., and Reichl, U. (2006). Production of hantavirus Puumala nucleocapsid protein in Saccharomyces cerevisiae for vaccine and diagnostics. J. Biotechnol. 124, 347-362. doi: 10.1016/j.jbiotec.2005.12.028

Barriga, G. P., Villalon-Letelier, F., Marquez, C. L., Bignon, E. A., Acuna, R., Ross, B. H., et al. (2016). Inhibition of the hantavirus fusion process by predicted domain III and stem peptides from glycoprotein Gc. PLoS Negl. Trop. Dis. 10:e0004799. doi: 10.1371/journal.pntd.0004799

Bayard, V., Kitsutani, P. T., Barria, E. O., Ruedas, L. A., Tinnin, D. S., Muñoz, C., et al. (2004). Outbreak of hantavirus pulmonary syndrome, Los Santos, Panama, 1999-2000. Emerg. Infect. Dis. 10, 1635-1642. doi: 10.3201/eid1009. 040143

Bergstedt Oscarsson, K., Brorstad, A., Baudin, M., Lindberg, A., Forssen, A., Evander, M., et al. (2016). Human Puumala hantavirus infection in northern Sweden; increased seroprevalence and association to risk and health factors. BMC Infect. Dis. 16:566. doi: 10.1186/s12879-016-1879-2 significantly enhance type I IFN responses and inhibit HTNV replication both in vitro and in vivo. We also demonstrated that lncRNA NEAT1 could positively regulate RIG-I-DDX60mediated IFN responses during HTNV infection and that overexpression of NEAT1 could restrain HTNV amplification both in vitro and in vivo. These results suggest that enhancing host IFN responses during the early infection phase may be a novel therapeutic strategy for HFRS and HCPS, while there is still much work to be done to translate basic medicine research to clinical practice.

\section{AUTHOR CONTRIBUTIONS}

RL and HM wrote the manuscript. JS, MH, and ZL provided published evidence. QZ made the phylogenetic tree. XJ, FZ, and XW edited, reviewed, and approved its final version.

\section{FUNDING}

This work was supported by grants from the National Science Foundation (Nos. 81772167, 81971563, 81602494, and 81671994) and the Key Research and Development Project of Shaanxi Province (No. 2019ZDLSF02-03).

\section{SUPPLEMENTARY MATERIAL}

The Supplementary Material for this article can be found online at: https://www.frontiersin.org/articles/10.3389/fmicb. 2019.02989/full\#supplementary-material

Bird, B. H., Shrivastava-Ranjan, P., Dodd, K. A., Erickson, B. R., and Spiropoulou, C. F. (2016). Effect of Vandetanib on Andes virus survival in the hamster model of Hantavirus pulmonary syndrome. Antiviral Res. 132, 66-69. doi: 10.1016/j. antiviral.2016.05.014

Brocato, R. L., and Hooper, J. W. (2019). Progress on the prevention and treatment of hantavirus disease. Viruses 11:E610. doi: 10.3390/v11070610

Brocato, R., Josleyn, M., Ballantyne, J., Vial, P., and Hooper, J. W. (2012). DNA vaccine-generated duck polyclonal antibodies as a postexposure prophylactic to prevent hantavirus pulmonary syndrome (HPS). PLoS one 7:e35996. doi: 10.1371/journal.pone.0035996

Brocato, R. L., Josleyn, M. J., Wahl-Jensen, V., Schmaljohn, C. S., and Hooper, J. W. (2013). Construction and nonclinical testing of a puumala virus synthetic M gene-based DNA vaccine.Clin.Vaccine Immunol. 20, 218-226. doi: 10.1128/ CVI.00546-12

Bucht, G., Sjolander, K. B., Eriksson, S., Lindgren, L., Lundkvist, A., and Elgh, F. (2001). Modifying the cellular transport of DNA-based vaccines alters the immune response to hantavirus nucleocapsid protein. Vaccine 19, 3820-3829. doi: 10.1016/s0264-410x(01)00151-7

Cheng, L. F., Wang, F., Zhang, L., Yu, L., Ye, W., Liu, Z. Y., et al. (2016). Incorporation of GM-CSF or CD40L enhances the immunogenicity of Hantaan virus-like particles. Front. Cell Infect. Microbiol. 6:185. doi: 10.3389/fcimb.2016. 00185

Chiang, C. F., Albarino, C. G., Lo, M. K., and Spiropoulou, C. F. (2014). Small interfering RNA inhibition of Andes virus replication. PLoS One 9:e99764. doi: 10.1371/journal.pone.0099764

Cho, H. W., Howard, C. R., and Lee, H. W. (2002). Review of an inactivated vaccine against hantaviruses. Intervirology 45, 328-333. doi: 10.1159/000067925 
Chung, D. H., Kumarapperuma, S. C., Sun, Y., Li, Q., Chu, Y. K., Arterburn, J. B., et al. (2008). Synthesis of 1-beta-D-ribofuranosyl-3-ethynyl-[1,2,4]triazole and its in vitro and in vivo efficacy against hantavirus. Antiviral Res. 79, 19-27. doi: $10.1016 /$ j.antiviral.2008.02.003

Chung, D. H., Vastermark, A., Camp, J. V., Mcallister, R., Remold, S. K., Chu, Y. K., et al. (2013). The murine model for Hantaan virus-induced lethal disease shows two distinct paths in viral evolutionary trajectory with and without ribavirin treatment. J. Virol. 87, 10997-11007. doi: 10.1128/JVI.01394-13

Cifuentes-Munoz, N., Barriga, G. P., Valenzuela, P. D., and Tischler, N. D. (2011). Aromatic and polar residues spanning the candidate fusion peptide of the Andes virus $\mathrm{Gc}$ protein are essential for membrane fusion and infection. J. Gen. Virol. 92, 552-563. doi: 10.1099/vir.0.027235-0

Custer, D. M., Thompson, E., Schmaljohn, C. S., Ksiazek, T. G., and Hooper, J. W. (2003). Active and passive vaccination against hantavirus pulmonary syndrome with Andes virus M genome segment-based DNA vaccine. J. Virol. 77, 9894-9905. doi: 10.1128/jvi.77.18.9894-9905.2003

de Carvalho Nicacio, C., Gonzalez Della Valle, M., Padula, P., Björling, E., Plyusnin, A., and Lundkvist, $\AA$ (2002). Cross-protection against challenge with Puumala virus after immunization with nucleocapsid proteins from different hantaviruses. J. Virol. 76, 6669-6677. doi: 10.1128/jvi.76.13.6669-6677.2002

de Carvalho Nicacio, C., Lundkvist, A., Sjolander, K. B., Plyusnin, A., Salonen, E. M., and Bjorling, E. (2000). A neutralizing recombinant human antibody Fab fragment against Puumala hantavirus. J. Med. Virol. 60, 446-454. doi: 10.1002/(sici)1096-9071(200004)60:4<446::aid-jmv13>3.0.co;2-v

Deng, H. Y., Luo, F., Shi, L. Q., Zhong, Q., Liu, Y. J., and Yang, Z. Q. (2009). Efficacy of arbidol on lethal hantaan virus infections in suckling mice and in vitro. Acta Pharmacol. Sin. 30, 1015-1024. doi: 10.1038/aps.2009.53

Dong, Y., Ma, T., Zhang, X., Ying, Q., Han, M., Zhang, M., et al. (2019). Incorporation of CD40 ligand or granulocyte-macrophage colony stimulating factor into Hantaan virus (HTNV) virus-like particles significantly enhances the long-term immunity potency against HTNV infection. J. Med. Microbiol. 68, 480-492. doi: 10.1099/jmm.0.000897

Duggan, J. M. (2019). Prevalence of Seoul hantavirus in UK wild rats: an emerging public health problem? Vet. Rec. 184, 523-524. doi: 10.1136/vr.11163

Echterdiek, F., Kitterer, D., Alscher, M. D., Schwenger, V., Ruckenbrod, B., Bald, M., et al. (2019). Clinical course of hantavirus-induced nephropathia epidemica in children compared to adults in Germany-analysis of 317 patients. Pediatr. Nephrol. 34, 1247-1252. doi: 10.1007/s00467-019-04215-9

Ettinger, J., Hofmann, J., Enders, M., Tewald, F., Oehme, R. M., Rosenfeld, U. M., et al. (2012). Multiple synchronous outbreaks of Puumala virus, Germany, 2010. Emerg. Infect. Dis. 18, 1461-1464. doi: 10.3201/eid1809.111447

Frese, M., Kochs, G., Feldmann, H., Hertkorn, C., and Haller, O. (1996). Inhibition of bunyaviruses, phleboviruses, and hantaviruses by human MxA protein. J. Virol. 70, 915-923. doi: 10.1128/jvi.70.2.915-923.1996

Garrido, J. L., Prescott, J., Calvo, M., Bravo, F., Alvarez, R., Salas, A., et al. (2018). Two recombinant human monoclonal antibodies that protect against lethal Andes hantavirus infection in vivo. Sci. Transl. Med. 10:eaat6420. doi: 10.1126/ scitranslmed.aat6420

Gavrilovskaya, I. N., Gorbunova, E. E., and Mackow, E. R. (2012). Andes virus infection of lymphatic endothelial cells causes giant cell and enhanced permeability responses that are rapamycin and vascular endothelial growth factor C sensitive. J. Virol. 86, 8765-8772. doi: 10.1128/JVI.00817-12

Gavrilovskaya, I. N., Gorbunova, E. E., Mackow, N. A., and Mackow, E. R. (2008). Hantaviruses direct endothelial cell permeability by sensitizing cells to the vascular permeability factor VEGF, while angiopoietin 1 and sphingosine 1phosphate inhibit hantavirus-directed permeability. J. Virol. 82, 5797-5806. doi: 10.1128/JVI.02397-07

Geldmacher, A., Schmaler, M., Kruger, D. H., and Ulrich, R. (2004). Yeastexpressed hantavirus Dobrava nucleocapsid protein induces a strong, longlasting, and highly cross-reactive immune response in mice. Viral. Immunol. 17, 115-122. doi: 10.1089/088282404322875511

Gorbunova, E. E., Gavrilovskaya, I. N., Pepini, T., and Mackow, E. R. (2011). VEGFR2 and Src kinase inhibitors suppress Andes virus-induced endothelial cell permeability. J. Virol. 85, 2296-2303. doi: 10.1128/JVI.02319-10

Gowen, B. B., Wong, M. H., Jung, K. H., Sanders, A. B., Mendenhall, M., Bailey, $\mathrm{K}$. W., et al. (2007). In vitro and in vivo activities of T-705 against arenavirus and bunyavirus infections. Antimicrob. Agents Chemother. 51, 3168-3176. doi: 10.1128/aac.00356-07
Graham, B. S., Gilman, M. S. A., and Mclellan, J. S. (2019). Structure-based vaccine antigen design. Annu. Rev. Med. 70, 91-104. doi: 10.1146/annurevmed-121217-094234

Gut, A. K., Gut, R., Rymarz, A., and Wozniak-Kosek, A. (2018). Hemorrhagic fever with renal syndrome (HFRS) in Poland. Przegl. Epidemiol. 72, 477-485. doi: $10.32394 /$ pe.72.4.23

Haese, N., Brocato, R. L., Henderson, T., Nilles, M. L., Kwilas, S. A., Josleyn, M. D., et al. (2015). Antiviral biologic produced in DNA vaccine/goose platform protects hamsters against hantavirus pulmonary syndrome when administered post-exposure. PLoS Negl. Trop. Dis. 9:e0003803. doi: 10.1371/journal.pntd. 0003803

Hall, P. R., Hjelle, B., Brown, D. C., Ye, C., Bondu-Hawkins, V., Kilpatrick, K. A., et al. (2008). Multivalent presentation of antihantavirus peptides on nanoparticles enhances infection blockade. Antimicrob. Agents Chemother. 52, 2079-2088. doi: 10.1128/AAC.01415-07

Hall, P. R., Leitao, A., Ye, C., Kilpatrick, K., Hjelle, B., Oprea, T. I., et al. (2010). Small molecule inhibitors of hantavirus infection. Bioorg. Med. Chem. Lett. 20, 7085-7091. doi: 10.1016/j.bmcl.2010.09.092

Hammerbeck, C. D., Brocato, R. L., Bell, T. M., Schellhase, C. W., Mraz, S. R., Queen, L. A., et al. (2016). Depletion of alveolar macrophages does not prevent hantavirus disease pathogenesis in golden syrian hamsters. J. Virol. 90, 62006215. doi: 10.1128/jvi.00304-16

Hooper, J. W., Custer, D. M., Smith, J., and Wahl-Jensen, V. (2006). Hantaan/Andes virus DNA vaccine elicits a broadly cross-reactive neutralizing antibody response in nonhuman primates. Virology 347, 208-216. doi: 10.1016/j.virol. 2005.11.035

Hooper, J. W., Custer, D. M., Thompson, E., and Schmaljohn, C. S. (2001). DNA vaccination with the Hantaan virus $\mathrm{M}$ gene protects Hamsters against three of four HFRS hantaviruses and elicits a high-titer neutralizing antibody response in Rhesus monkeys. J. Virol. 75, 8469-8477. doi: 10.1128/jvi.75.18.8469-8477. 2001

Hooper, J. W., Ferro, A. M., and Wahl-Jensen, V. (2008). Immune serum produced by DNA vaccination protects hamsters against lethal respiratory challenge with Andes virus. J. Virol. 82, 1332-1338. doi: 10.1128/jvi.01822-07

Hooper, J. W., Josleyn, M., Ballantyne, J., and Brocato, R. (2013). A novel Sin Nombre virus DNA vaccine and its inclusion in a candidate pan-hantavirus vaccine against hantavirus pulmonary syndrome (HPS) and hemorrhagic fever with renal syndrome (HFRS). Vaccine 31, 4314-4321. doi: 10.1016/j.vaccine. 2013.07.025

Hooper, J. W., Kamrud, K. I., Elgh, F., Custer, D., and Schmaljohn, C. S. (1999). DNA vaccination with hantavirus $M$ segment elicits neutralizing antibodies and protects against Seoul virus infection. Virology 255, 269-278. doi: 10.1006/viro. 1998.9586

Hooper, J. W., Moon, J. E., Paolino, K. M., Newcomer, R., Mclain, D. E., Josleyn, M., et al. (2014). A Phase 1 clinical trial of Hantaan virus and Puumala virus M-segment DNA vaccines for haemorrhagic fever with renal syndrome delivered by intramuscular electroporation. Clin. Microbiol. Infect. 20(Suppl. 5), 110-117. doi: 10.1111/1469-0691.12553

Huggins, J. W., Hsiang, C. M., Cosgriff, T. M., Guang, M. Y., Smith, J. I., Wu, Z. O., et al. (1991). Prospective, double-blind, concurrent, placebocontrolled clinical trial of intravenous ribavirin therapy of hemorrhagic fever with renal syndrome. J. Infect. Dis. 164, 1119-1127. doi: 10.1093/infdis/164.6. 1119

Huggins, J. W., Kim, G. R., Brand, O. M., and Mckee, K. T. Jr. (1986). Ribavirin therapy for Hantaan virus infection in suckling mice. J. Infect. Dis. 153, 489-497. doi: 10.1093/infdis/153.3.489

Jiang, H., Du, H., Wang, L. M., Wang, P. Z., and Bai, X. F. (2016). Hemorrhagic fever with renal syndrome: pathogenesis and clinical picture. Front. Cell Infect. Microbiol. 6:1. doi: 10.3389/fcimb.2016.00001

Jiang, D., Sun, Y., Cheng, L., Zhang, G., Dong, C., and Jin, B. (2015). Construction and evaluation of DNA vaccine encoding Hantavirus glycoprotein N-terminal fused with lysosome-associated membrane protein. Vaccine 33, 3367-3376.doi: 10.1016/j.vaccine.2015.05.007

Jiang, F., Wang, L., Wang, S., Zhu, L., Dong, L., Zhang, Z., et al. (2017). Meteorological factors affect the epidemiology of hemorrhagic fever with renal syndrome via altering the breeding and hantavirus-carrying states of rodents and mites: a 9 years' longitudinal study. Emerg. Microbes Infect. 6:e104. doi: 10.1038/emi.2017.92 
Johansson, P., Olsson, M., Lindgren, L., Ahlm, C., Elgh, F., Holmstrom, A., et al. (2004). Complete gene sequence of a human Puumala hantavirus isolate, Puumala Umea/hu: sequence comparison and characterisation of encoded gene products. Virus Res. 105, 147-155. doi: 10.1016/j.virusres.2004.05.005

Jung, J., Ko, S. J., Oh, H. S., Moon, S. M., Song, J. W., and Huh, K. (2018). Protective effectiveness of inactivated hantavirus vaccine against hemorrhagic fever with renal syndrome. J. Infect. Dis. 217, 1417-1420. doi: 10.1093/infdis/jiy037

Kerins, J. L., Koske, S. E., Kazmierczak, J., Austin, C., Gowdy, K., and Dibernardo, A. (2018). Outbreak of Seoul virus among rats and rat owners - United States and Canada, 2017. Can. Commun. Dis. Rep. 44, 71-74. doi: 10.14745/ccdr. v44i02a07

Kobayashi, T., Nakatsuka, K., Shimizu, M., Tamura, H., Shinya, E., Atsukawa, M., et al. (2012). Ribavirin modulates the conversion of human CD4(+) CD25(-) $\mathrm{T}$ cell to $\mathrm{CD} 4(+) \mathrm{CD} 25(+) \mathrm{FOXP} 3(+) \mathrm{T}$ cell via suppressing interleukin10-producing regulatory T cell. Immunology 137, 259-270. doi: 10.1111/imm. 12005

Kruger, D. H., Ulrich, R. G., and Hofmann, J. (2013). Hantaviruses as zoonotic pathogens in Germany. Dtsch. Arztebl. Int. 110, 461-467. doi: 10.3238/arztebl. 2013.0461

Kwilas, S., Kishimori, J. M., Josleyn, M., Jerke, K., Ballantyne, J., Royals, M., et al. (2014). A hantavirus pulmonary syndrome (HPS) DNA vaccine delivered using a spring-powered jet injector elicits a potent neutralizing antibody response in rabbits and nonhuman primates. Curr. Gene Ther. 14, 200-210. doi: 10.2174/ 1566523214666140522122633

Laine, O., Leppanen, I., Koskela, S., Antonen, J., Makela, S., Sinisalo, M., et al. (2015). Severe Puumala virus infection in a patient with a lymphoproliferative disease treated with icatibant. Infect. Dis. 47, 107-111. doi: 10.3109/00365548. 2014.969304

Li, S., Rissanen, I., Zeltina, A., Hepojoki, J., Raghwani, J., Harlos, K., et al. (2016). A molecular-level account of the antigenic hantaviral surface. Cell Rep. 15, 959-967. doi: 10.1016/j.celrep.2016.03.082

Li, Z., Zeng, H., Wang, Y., Zhang, Y., Cheng, L., Zhang, F., et al. (2017). The assessment of Hantaan virus-specific antibody responses after the immunization program for hemorrhagic fever with renal syndrome in northwest China. Hum. Vaccin. Immunother. 13, 802-807. doi: 10.1080/ 21645515.2016.1253645

Liang, H., Yang, R., Liu, Z., Li, M., Liu, H., and Jin, X. (2018). Recombinant Zika virus envelope protein elicited protective immunity against Zika virus in immunocompetent mice. PLoS One 13:e0194860. doi: 10.1371/journal.pone. 0194860

Limongi, J. E., Da Costa, F. C., Pinto, R. M., De Oliveira, R. C., Bragagnolo, C., Lemos, E. R., et al. (2009). Cross-sectional survey of hantavirus infection, Brazil. Emerg. Infect. Dis. 15, 1981-1983. doi: 10.3201/eid1512.090229

Mackow, E. R., Dalrymple, N. A., Cimica, V., Matthys, V., Gorbunova, E., and Gavrilovskaya, I. (2014). Hantavirus interferon regulation and virulence determinants. Virus Res. 187, 65-71. doi: 10.1016/j.virusres.2013.12.041

Maes, P., Clement, J., Cauwe, B., Bonnet, V., Keyaerts, E., Robert, A., et al. (2008). Truncated recombinant puumala virus nucleocapsid proteins protect mice against challenge in vivo. Viral Immunol. 21, 49-60. doi: 10.1089/vim.2007.0059

Malinin, O. V., and Platonov, A. E. (2017). Insufficient efficacy and safety of intravenous ribavirin in treatment of haemorrhagic fever with renal syndrome caused by Puumala virus. Infect. Dis. 49, 514-520. doi: 10.1080/23744235.2017. 1293841

Manigold, T., and Vial, P. (2014). Human hantavirus infections: epidemiology, clinical features, pathogenesis and immunology. Swiss Med. Wkly. 144:w13937.

Mertz, G. J., Miedzinski, L., Goade, D., Pavia, A. T., Hjelle, B., Hansbarger, C. O., et al. (2004). Placebo-controlled, double-blind trial of intravenous ribavirin for the treatment of hantavirus cardiopulmonary syndrome in North America. Clin. Infect. Dis. 39, 1307-1313. doi: 10.1086/425007

Murphy, M. E., Kariwa, H., Mizutani, T., Tanabe, H., Yoshimatsu, K., Arikawa, J., et al. (2001). Characterization of in vitro and in vivo antiviral activity of lactoferrin and ribavirin upon hantavirus. J. Vet. Med. Sci. 63, 637-645. doi: 10.1292/jvms.63.637

Murphy, M. E., Kariwa, H., Mizutani, T., Yoshimatsu, K., Arikawa, J., and Takashima, I. (2000). In vitro antiviral activity of lactoferrin and ribavirin upon hantavirus. Arch. Virol. 145, 1571-1582. doi: 10.1007/s007050070077

Ogg, M., Jonsson, C. B., Camp, J. V., and Hooper, J. W. (2013). Ribavirin protects Syrian hamsters against lethal hantavirus pulmonary syndrome-after intranasal exposure to Andes virus. Viruses 5, 2704-2720. doi: 10.3390/v5112704
Padula, P., Martinez, V. P., Bellomo, C., Maidana, S., San Juan, J., Tagliaferri, P., et al. (2007). Pathogenic hantaviruses, northeastern Argentina and eastern Paraguay. Emerg. Infect. Dis. 13, 1211-1214. doi: 10.3201/eid1308.061090

Pal, E., Korva, M., Resman Rus, K., Kejzar, N., Bogovic, P., Strle, F., et al. (2018). Relationship between circulating vascular endothelial growth factor and its soluble receptor in patients with hemorrhagic fever with renal syndrome. Emerg. Microbes Infect. 7:89. doi: 10.1038/s41426-018-0090-5

Pini, N., Levis, S., Calderón, G., Ramirez, J., Bravo, D., Lozano, E., et al. (2003). Hantavirus infection in humans and rodents, Northwestern Argentina. Emerg. Infect. Dis. 9, 1070-1076. doi: 10.3201/eid0909.020768

Prince, H. E., and Lieberman, J. M. (2013). Impact of the Yosemite hantavirus outbreak on hantavirus antibody testing at a national reference laboratory. Clin. Vaccine Immunol. 20, 1213-1216. doi: 10.1128/CVI.00326-13

Qian, D. Y., Ding, Y. S., Chen, G. F., Ding, J. J., Chen, Y. X., Lu, T. F., et al. (1990). A placebo-controlled clinical trial of prednisone in the treatment of early hemorrhagic fever. J. Infect. Dis. 162, 1213-1214. doi: 10.1093/infdis/162. 5.1213

Qu, P., Zhang, W., Li, D., Zhang, C., Liu, Q., Zhang, X., et al. (2018). Insect cell-produced recombinant protein subunit vaccines protect against $Z i k a$ virus infection. Antivir. Res. 154, 97-103. doi: 10.1016/j.antiviral.2018.04.010

Razanskiene, A., Schmidt, J., Geldmacher, A., Ritzi, A., Niedrig, M., Lundkvist, Å, et al. (2004). High yields of stable and highly pure nucleocapsid proteins of different hantaviruses can be generated in the yeast Saccharomyces cerevisiae. J. Biotechnol. 111, 319-333. doi: 10.1016/j.jbiotec.2004.04.010

Rissanen, I., Stass, R., Zeltina, A., Li, S., Hepojoki, J., Harlos, K., et al. (2017). Structural transitions of the conserved and metastable hantaviral glycoprotein envelope. J. Virol. 91:e378-17. doi: 10.1128/JVI.00378-17

Safronetz, D., Falzarano, D., Scott, D. P., Furuta, Y., Feldmann, H., and Gowen, B. B. (2013). Antiviral efficacy of favipiravir against two prominent etiological agents of hantavirus pulmonary syndrome. Antimicrob. Agents Chemother. 57, 4673-4680. doi: 10.1128/AAC.00886-13

Safronetz, D., Haddock, E., Feldmann, F., Ebihara, H., and Feldmann, H. (2011). In vitro and in vivo activity of ribavirin against Andes virus infection. PLoS One 6:e23560. doi: 10.1371/journal.pone.0023560

Salim, N. N., Ganaie, S. S., Roy, A., Jeeva, S., and Mir, M. A. (2016). Targeting a novel RNA-protein interaction for therapeutic intervention of Hantavirus disease. J. Biol. Chem. 291, 24702-24714. doi: 10.1074/jbc.m116.750729

Sargianou, M., Watson, D. C., Chra, P., Papa, A., Starakis, I., Gogos, C., et al. (2012). Hantavirus infections for the clinician: from case presentation to diagnosis and treatment. Crit. Rev. Microbiol. 38, 317-329. doi: 10.3109/1040841X.2012. 673553

Sayer, W. J., Entwhisle, G., Uyeno, B., and Bignall, R. C. (1955). Cortisone therapy of early epidemic hemorrhagic fever: a preliminary report. Ann. Intern. Med. 42, 839-851.

Schmaljohn, C. S. (2012). Vaccines for hantaviruses: progress and issues. Expert Rev. Vaccines 11, 511-513. doi: 10.1586/erv.12.15

Schmaljohn, C. S., Spik, K. W., and Hooper, J. W. (2014). DNA vaccines for HFRS: laboratory and clinical studies. Virus Res. 187, 91-96. doi: 10.1016/j.virusres. 2013.12.020

Schmidt, J., Jandrig, B., Klempa, B., Yoshimatsu, K., Arikawa, J., Meisel, H., et al. (2005). Nucleocapsid protein of cell culture-adapted Seoul virus strain 80-39: analysis of its encoding sequence, expression in yeast and immuno-reactivity. Virus Genes 30, 37-48. doi: 10.1007/s11262-004-4580-2

Schonrich, G., and Raftery, M. J. (2017). Exploring the immunopathogenesis of viral hemorrhagic fever in mice with a humanized immune system. Front. Immunol. 8:1202. doi: 10.3389/fimmu.2017.01202

Song, J. Y., Woo, H. J., Cheong, H. J., Noh, J. Y., Baek, L. J., and Kim, W. J. (2016). Long-term immunogenicity and safety of inactivated Hantaan virus vaccine (Hantavax) in healthy adults. Vaccine 34, 1289-1295. doi: 10.1016/j.vaccine. 2016.01.031

Spik, K. W., Badger, C., Mathiessen, I., Tjelle, T., Hooper, J. W., and Schmaljohn, C. (2008). Mixing of M segment DNA vaccines to Hantaan virus and Puumala virus reduces their immunogenicity in hamsters. Vaccine 26, 5177-5181.doi: 10.1016/j.vaccine.2008.03.097

Stanojevic, M., Cirkovic, V., Siljic, M., Gligic, A., and Stamenkovic, G. (2019). Molecular characterization of Dobrava-Belgrade hantavirus in Serbia, 20072011. J. Infect. Public Health 12, 645-649. doi: 10.1016/j.jiph.2019.02.021

Sun, J., Li, M., Wang, Y., Hao, P., and Jin, X. (2017). Elaboration of tetravalent antibody responses against dengue viruses using a subunit vaccine comprised 
of a single consensus dengue envelope sequence. Vaccine 35, 6308-6320. doi: 10.1016/j.vaccine.2017.09.063

Suzuki, A., Bisordi, I., Levis, S., Garcia, J., Pereira, L. E., Souza, R. P., et al. (2004). Identifying rodent hantavirus reservoirs, Brazil. Emerg. Infect. Dis. 10, 2127-2134. doi: 10.3201/eid1012.040295

Szabo, R. (2017). Antiviral therapy and prevention against hantavirus infections. Acta Virol. 61, 3-12. doi: 10.4149/av_2017_01_3

Taylor, S. L., Wahl-Jensen, V., Copeland, A. M., Jahrling, P. B., and Schmaljohn, C. S. (2013). Endothelial cell permeability during hantavirus infection involves factor XII-dependent increased activation of the kallikrein-kinin system. PLoS Pathog. 9:e1003470. doi: 10.1371/journal.ppat.1003470

Terajima, M., Van Epps, H. L., Li, D., Leporati, A. M., Juhlin, S. E., Mustonen, J., et al. (2002). Generation of recombinant vaccinia viruses expressing Puumala virus proteins and use in isolating cytotoxic T cells specific for Puumala virus. Virus Res. 84, 67-77. doi: 10.1016/s0168-1702(01)00416-6

Tian, H., and Stenseth, N. C. (2019). The ecological dynamics of hantavirus diseases: from environmental variability to disease prevention largely based on data from China. PLoS Negl. Trop. Dis. 13:e0006901. doi: 10.1371/journal.pntd. 0006901

Tian, H., Yu, P., Cazelles, B., Xu, L., Tan, H., Yang, J., et al. (2017). Interannual cycles of Hantaan virus outbreaks at the human-animal interface in Central China are controlled by temperature and rainfall. Proc. Natl. Acad. Sci. U.S.A. 114, 8041-8046. doi: 10.1073/pnas.1701777114

Toro, J., Vega, J. D., Khan, A. S., Mills, J. N., Padula, P., Terry, W., et al. (1998). An outbreak of hantavirus pulmonary syndrome, Chile, 1997. Emerg. Infect. Dis. 4, 687-694. doi: 10.3201/eid0404.980425

Vaheri, A., Henttonen, H., Voutilainen, L., Mustonen, J., Sironen, T., and Vapalahti, O. (2013). Hantavirus infections in Europe and their impact on public health. Rev. Med. Virol. 23, 35-49. doi: 10.1002/rmv.1722

Vial, P. A., Valdivieso, F., Calvo, M., Rioseco, M. L., Riquelme, R., Araneda, A., et al. (2015). A non-randomized multicentre trial of human immune plasma for treatment of hantavirus cardiopulmonary syndrome caused by Andes virus. Antivir. Ther. 20, 377-386. doi: 10.3851/IMP2875

Vial, P. A., Valdivieso, F., Ferres, M., Riquelme, R., Rioseco, M. L., Calvo, M., et al. (2013). High-dose intravenous methylprednisolone for hantavirus cardiopulmonary syndrome in Chile: a double-blind, randomized controlled clinical trial. Clin. Infect. Dis. 57, 943-951. doi: 10.1093/cid/ cit394

Wang, W., Zhang, Y., Li, Y., Pan, L., Bai, L., Zhuang, Y., et al. (2012). Dysregulation of the beta3 integrin-VEGFR2 complex in Hantaan virusdirected hyperpermeability upon treatment with VEGF. Arch. Virol. 157, 1051-1061. doi: 10.1007/s00705-012-1245-7

Westover, J. B., Sefing, E. J., Bailey, K. W., Van Wettere, A. J., Jung, K. H., Dagley, A., et al. (2016). Low-dose ribavirin potentiates the antiviral activity of favipiravir against hemorrhagic fever viruses. Antivir. Res. 126, 62-68. doi: 10.1016/j.antiviral.2015.12.006

Xu, R., Yang, X. Y., Yang, D. F., Zou, C. Y., Gong, P. L., and Zeng, F. D. (2009). Phase I evaluation of the safety and pharmacokinetics of a single-dose intravenous injection of a murine monoclonal antibody against Hantaan virus in healthy volunteers. Antimicrob. Agents Chemother. 53, 5055-5059. doi: 10.1128/AAC. 00728-09

$\mathrm{Xu}$, Z., Wei, L., Wang, L., Wang, H., and Jiang, S. (2002). The in vitro and in vivo protective activity of monoclonal antibodies directed against Hantaan virus: potential application for immunotherapy and passive immunization. Biochem. Biophys. Res. Commun. 298, 552-558. doi: 10.1016/s0006-291x(02) 02491-9

Xu-Yang, Z., Pei-Yu, B., Chuan-Tao, Y., Wei, Y., Hong-Wei, M., Kang, T., et al. (2016). Interferon-induced transmembrane protein 3 inhibits Hantaan virus infection, and its single nucleotide polymorphism rs12252 influences the severity of hemorrhagic fever with renal syndrome. Front. Immunol. 7:535. doi: 10.3389/fimmu.2016.00535

Yamanishi, K., Tanishita, O., Tamura, M., Asada, H., Kondo, K., Takagi, M., et al. (1988). Development of inactivated vaccine against virus causing haemorrhagic fever with renal syndrome. Vaccine 6, 278-282. doi: 10.1016/0264-410x(88) 90224-1

Yang, J., Sun, J. F., Wang, T. T., Guo, X. H., Wei, J. X., Jia, L. T., et al. (2017). Targeted inhibition of hantavirus replication and intracranial pathogenesis by a chimeric protein-delivered siRNA. Antivir. Res. 147, 107-115. doi: 10.1016/j. antiviral.2017.10.005

Yi, Y., Park, H., and Jung, J. (2018). Effectiveness of inactivated hantavirus vaccine on the disease severity of hemorrhagic fever with renal syndrome. Kidney Res. Clin. Pract. 37, 366-372. doi: 10.23876/j.krcp.18.0044

Ying, Q., Ma, T., Cheng, L., Zhang, X., Truax, A. D., Ma, R., et al. (2016). Construction and immunological characterization of CD40L or GM-CSF incorporated Hantaan virus like particle. Oncotarget 7, 63488-63503. doi: 10. 18632/oncotarget.11329

Yong, C. Y., Ong, H. K., Yeap, S. K., Ho, K. L., and Tan, W. S. (2019). Recent advances in the vaccine development against middle east respiratory syndrome-coronavirus. Front. Microbiol. 10:1781. doi: 10.3389/fmicb.2019. 01781

Zhang, S., Wang, S., Yin, W., Liang, M., Li, J., Zhang, Q., et al. (2014). Epidemic characteristics of hemorrhagic fever with renal syndrome in China, 2006-2012. BMC Infect. Dis 14:384. doi: 10.1186/1471-2334-14-384

Zhang, X. K., Takashima, I., and Hashimoto, N. (1989). Characteristics of passive immunity against hantavirus infection in rats. Arch. Virol. 105, 235-246. doi: 10.1007/bf01311360

Zhao, C., Sun, Y., Zhao, Y., Wang, S., Yu, T., Du, F., et al. (2012). Immunogenicity of a multi-epitope DNA vaccine against hantavirus. Hum. Vaccin. Immunother. 8, 208-215. doi: 10.4161/hv.18389

Zheng, Y., Zhou, B. Y., Wei, J., Xu, Y., Dong, J. H., Guan, L. Y., et al. (2018). Persistence of immune responses to vaccine against haemorrhagic fever with renal syndrome in healthy adults aged 16-60 years: results from an openlabel2-year follow-up study. Infect. Dis. 50, 21-26. doi: 10.1080/23744235.2017. 1353704

Conflict of Interest: The authors declare that the research was conducted in the absence of any commercial or financial relationships that could be construed as a potential conflict of interest.

Copyright (c) $2020 \mathrm{Liu}, \mathrm{Ma}$, Shu, Zhang, Han, Liu, Jin, Zhang and Wu. This is an open-access article distributed under the terms of the Creative Commons Attribution License (CC BY). The use, distribution or reproduction in other forums is permitted, provided the original author(s) and the copyright owner(s) are credited and that the original publication in this journal is cited, in accordance with accepted academic practice. No use, distribution or reproduction is permitted which does not comply with these terms. 